\title{
Sergileme Mekânlarında Yapay Aydınlatma Uygulamaları
}

\author{
Merve KARAOĞLU CAN ${ }^{1 *}$, Damla ALTUNCU ${ }^{2}$
}

Öz

Müzelerin en önemli mekânı olan sergileme mekânları, ziyaretçilerin müzeye geliş amaçlarına cevap verebilir nitelikte olmalıdır. Günümüzde, görsel etkinin arttırılması amacı ile de tasarlanan bu mekânlarda aydınlatma, sergilenecek olan eserlerin doğru algılanması ve zaman içerisinde oluşabilecek olan bozulmaların en aza indirgenmesi açısından son derece önemlidir. Dolayısıyla, bu mekânların tasarım özelliklerine ve verilmek istenen etkiye bağlı olarak uygun nicelik ve nitelikte aydınlatma uygulamalarının yapılması gerekmektedir. Ziyaretçinin sergiyi algılayabilmesine bağlı olarak gelişecek haz duyma ile mekân içerisinde daha çok vakit geçirme, mekânda tekrar bulunma istekleri süreklilik kazanacaktır. Bu noktadan hareketle çalışmada müzelerin koruma, sergileme ve eğitim işlevlerini en iyi şekilde yerine getirmesine destek sağlayacak görsel konfor koşulları çerçevesinde Osmanlı Bankası Müzesi, SALT Galata yapısı içerisindeki süreli-sürekli sergileme mekânları örnek olay tarama modeline uygun olarak incelenmiştir.

Anahtar Kelimeler: Sergileme, Yapay Aydınlatma, SALT Galata, Osmanlı Bankası Müzesi

\section{Artificial Lighting Applications in Exhibition Spaces}

\begin{abstract}
The exhibition spaces, which are the most important spaces of the museums, should be able to respond to the purpose of the visitors. Nowadays, lighting in these spaces, which are also designed to increase the visual effect, is extremely important in terms of the correct perception of the works to be exhibited and the minimization of deteriorations that may occur over time. Therefore, depending on the design features of these spaces and the desired effect, lighting applications of appropriate quantity and quality should be made. With the pleasure that will develop depending on the visitor's perception of the exhibition, the desire to spend more time in the space and to be in the space again will gain continuity. From this point of view -within the framework of visual comfort conditions that will support museums to fulfill their preservation, exhibition and educational functions in the best way- the Ottoman Bank Museum, the temporarypermanent exhibition spaces within the SALT Galata and the 'Open Archive' are examined in accordance with the case study model.
\end{abstract}

Keywords: Exhibition, Artificial Lighting, SALT Galata, Ottoman Bank Museum

\footnotetext{
${ }^{1}$ Kütahya Dumlupınar Üniversitesi, Mimarlık Fakültesi, İç Mimarlık Bölümü, 43100, Kütahya

${ }^{2}$ Mimar Sinan Güzel Sanatlar Üniversitesi, Mimarlık Fakültesi, İç Mimarlık Bölümü, 34427, İstanbul

* Bu çalışma Mimar Sinan Güzel Sanatlar Üniversitesi İç Mimarlık Anabilim Dalı'nda Doç.Dr.Damla Altuncu danışmanlığında hazırlanan 'Müzelerin Sergileme Mekânlarında Yenilikçi Yapay Aydınlatma Uygulamalarının Görsel Konfor Koşulları Açısından İncelenmesi: Salt Galata Örneği' isimli Yüksek Lisans Tezi'nden üretilmiştir.

* İlgili yazar/Corresponding Author: mervekaraoglucan@gmail.com

Gönderim Tarihi / Received Date: 08.05.2021

Kabul Tarihi / Accepted Date: 26.08.2021
} 


\section{Giriş}

Müze kelimesinin kökleri Antik Yunan dönemindeki şiire, tarihe, müziğe vs. adanmış ilham perilerine ve bu perilerin tapınakları olarak bilinen 'museion' isimli mekânlara dayanmaktadır. İngilizce karşılığı 'muse' kelimesinden türetilmiş museum/müze; Türk Dil Kurumu (TDK)'na göre; "sanat ve bilim eserlerinin veya sanat ve bilime yarayan nesnelerin saklandığı, halka gösterilmek için sergilendiği yer veya yapı" (Url-1), Uluslararası Müze Konseyi (ICOM-International Council of Museums)'nin Milano'da düzenlenen 22.Genel Konferansı'nda geliştirilen en güncel açıklamalarına göre ise; "insanoğlunun ve çevresinin somut ve somut olmayan mirasını, eğitim, çalışma ve insanlığın estetik hazzı için toplayan, koruyan, araştıran, ileten ve sergileyen, halka açık, toplumun ve toplumun gelişiminin hizmetinde olan, kâr amacı gütmeyen kalıcı bir kuruluş" (Url-2) tur. Müzeciliğin ortaya çıktığı ilk yıllarında karşılaşılan daha fazla eser sergileme amacı, tanımlarda da görülebileceği gibi süreç içerisinde koruma ve eğitim işlevleri ile desteklenmiştir. Bu sebeple eserin korunmasını etkileyecek gösterim teknikleri de zamanla gelişim göstermiş, özellikle yeni teknolojilerin getirdiklerine paralel olarak değişen aydınlatma uygulamalarının eserler ile olan ilişkisi dikkat edilmesi gereken unsurlardan biri haline gelmiştir. Kurtay vd.'ne göre;

- "bilinçli kullanılmış bir aydınlatma düzeni ile sergilenen nesnelerin görünmesini engelleyen kamaşmanın yok edilmesi, nesnelerin net ve doğru bir şekilde algılanmasının sağlanarak nitelikli bir izleme imkânının tanınması

- sergilenen nesnelerin zararlı ışınımlardan korunması

- gün ışığını destekleyici yapay aydınlatma düzeninin sağlanması

- sergileme yöntemlerinin gelişmesine bağlı olarak nesnelerin biçimsel, gereçsel, renksel vb. özelliklerinin ortaya çıkarılması (Kurtay vd., 2003, s.97)"

galeri ve müze aydınlatmasında üzerinde durulması gereken önemli noktalardır.

Ziyaretçi ile eser arasındaki ilişkide sürekliliğin sağlanabilmesi, toplumun müzelere olan ilgisinin arttırılabilmesi ve müzenin edindiği temel amaç olan eğitimin çerçevesinin genişletilebilmesi sergileme mekânlarında konfor koşullarının yerine getirilmesi ile desteklenecektir. Bu çalışmada müzelerin sergileme mekânlarında -üstlendikleri işlev, amaç ve görevleri paralelinde- iç mekân aydınlatmasının fiziksel iyi olma koşullarına bağlı olarak nasıl çözülmesi gerektiğine dair teorik bilgilerin sunulması, daha sonra da bu bilgilerin örnek bir olay üzerinde incelenmesi amaçlanmaktadır.

\section{Genel Tanım ve Kavramlar:}

\subsection{Sergileme Tür ve Tipleri}

Bir müze sahip olduğu koleksiyonla birlikte büyümekte, bu koleksiyon sebebiyle müze olarak tanımlanmakta ve yine bu koleksiyonla halka hizmet sunmakta, kültürel gelişime katkı sağlamaktadır. Bu sebeple, eserler sergileme mekânlarının tasarımında önemli bir yer tutmaktadır. Koleksiyon temelli sergilemelerin sınıflandırıması araştırmacılar tarafından çeşitli şekillerde ele alınmaktadır. Örneğin Bayer (2007, s.6-7) sergileme sürelerine bağlı olarak sergi türlerini sürekli, süreli ve gezici olmak üzere üçe ayırırken, Erbay (2011, s.75-85) zaman odaklı, mekânsız, sosyal odaklı, eser odaklı, sanatçı odaklı, tasarım odaklı ve koleksiyon odaklı sergiler olmak üzere daha geniş bir sınıflandırma ortaya koymaktadır.

Sergilemenin en önemli unsurlarından biri izleyici/ ziyaretçidir. Bu sebeple, izleyiciye koleksiyonların nasıl sunulacağı ön planda tutularak sınıflandırma yapmak da doğru bir yaklaşım olarak görülmektedir. Bu anlayışa göre sergilemede sunum tipleri beş gruba ayrılmaktadır (Bayer, 2007, s.5-6); 
- eserlerin sunulması ve yorumlanması yanında ziyaretçilerden alacağı tepkinin göz önüne alındığı sergiler; hissi sergileme (sanatsal/ estetik sergileme ve duygusal sergileme), öğretici/ eğitici sergileme, eğlendirici/ hoşa gidici sergileme

- eserlerin, mekanik ya da otomatik sistemlerle hareket etmediği durağan sergiler

- ziyaretçi tarafından hareket ettirilebilen mekanik eserlerin yer aldığı dinamik sergiler

- ziyaretçilerin beklentilerine göre düzenlenen ve bu intiyaçların teknolojik çözümlerle, bilgisayar programları ile ve film gösterimleri gibi tekniklerle giderildiği etkileşimli/interaktif sergiler

- hem eserin hem konunun önemli olduğu ve eserlerin bir hikayeyi açıklayıcı şekilde düzenlendiği tematik sergiler.

Geniş koleksiyona sahip olan müzeler, belirtilen sergileme tür ve tiplerinden birkaçını bir arada uygulayabilmektedirler. Ziyaretçilerin sergilenen eserleri en iyi şekilde algılayabilmelerinde yapılmış olan bu sınıflandırmalar büyük önem taşımaktadır. Atagök (2002, s.58); müzelerin anlaşılır kılınması ile ilgili kaleme aldığı bir çalışmasında insanların farklı zekâ ve öğrenme yöntemlerine sahip olduğunu, bu yüzden günümüzde sadece salt görsel imgeler değil, diğer duyular da dikkate alınarak sergileme mekânlarının kurgulanması gerektiğini vurgulamaktadır. Buna paralel olarak Atasoy (1994, s.99) müze sergilemelerinin analizinde dikkat edilmesi gereken üç önemli unsuru; sergilenen eserlerin verdiği etki, sergi alanının düzenlenmesi, serginin konusuna yaklaşım olarak özetlemekte ve bu üç unsurdan herhangi birinin diğerine göre daha vurgulu ya da ağırlıklı olarak tercih edilmemesi gerektiğini belirtilmektedir. Öncelikli olarak verilmiş olan 'sergilenen eserlerin verdiği etkinin ve buna bağlı olarak 'sergi alanlarının düzenlenmesi'nin insan-yapıt arasındaki ilişki üzerinde büyük bir etkisi bulunmaktadır. Atagök bu ilişkiden kaynaklanan ve birbiriyle çatışan iki farklı görüş olduğunu "nötr- yansız bir ortamda sanat yapıtlarının ön plana çıkartılarak sergilendiği müze mimarisi görüşü ve sanat yapıtlarını müze binasıyla bütünleştiren, ya da bir başka ifadeyle sanat yapıtını mimariyle birlikte algılayan, algılattıran görüş" (Atagök, 1999, s.74) şeklinde açıklamaktadır. Burada yansız olarak ifade edilmiş sergileme anlayışı Brian O'Doherty tarafından ortaya atılan ve ideal galeri mekânını sanat yapıtının 'sanat' olarak algılanışına engel oluşturan her türlü öğeyi dışlayan mekân olarak açıklayan 'beyaz küp' olgusu ile örtüşmektedir. Beyaz küp'e göre "dış dünyayla her türlü temas engellenmelidir, dolayısıyla pencereler genellikle yok edilir. Duvarlar beyazdır. Ana ışık kaynağı tavandır. Ahşap parkeler kendi ayak seslerinizi duyabileceğiniz kadar cilalıdır ya da sessizce adım atabileceğiniz şekilde halı kaplıdır, gözler duvarlardadır" (O'Doherty, 2010, s.30). Dolayısıyla sergileme mekânlarında kullanılan her türlü elemanın- zemin, duvar, tavan malzemeleri başta olmak üzere, oturma elemanları, yangın tüpleri, ısıtma/havalandırma sistem detayları, yapı malzemeleri dahil olmak üzere- odak noktası haline gelmesi engellenmeli, izleyicinin sadece yapıtlar ile ilişki kurması sağlanmalıdır. Müze sergilemelerinde dikkat edilmesi gereken 'sergi konusuna yaklaşım' ise öncelikli olarak koleksiyon içeriklerine göre farklılaşan sergileme türlerine, daha sonra da müzelerin kendi içinde sergiyi ele alışlarına göre değişiklik göstermektedir. Bu farklılıklar müzenin amacı, koleksiyonu, vermek istediği mesaj ya da hedef kitle profilleri gibi unsurlardan da etkilenmektedir.

\subsection{Müze Sergileme Mekânlarında Aydınlatma}

Bir serginin düzenlenmesinde algısal, bilişsel, kültürel veriler belirleyici rol oynar. Serginin çevreden alacağı ilgi kültürel verilerin bir geri bildirimidir, ancak kapsamında algısal ve bilişsel verilerin de ürününü barınır. Bu doğrultuda Erkün Oruçoğlu, bir serginin kurgusunun bu üç veri ile değerlendirilmesi gerektiğini belirtmektedir. Algısal 
veriler içerisinde insanın sahip olduğu görme, işitme, dokunma, koklama, tat alma ve pozisyon duyuları fiziksel çevre koşullarının fark edilmesini sağlamaktadır (Erkün Oruçoğlu, 1999, s.182-183). Sergileme de temelde tüm duyulara hitap eden bir etkinlik olarak tanımlanmaktadır. Ancak, özellikle görselliğin ön planda tutulması, ziyaretçinin görme duyusunun sunulanı algılama sürecinde çok daha etkin bir rol oynamasını sağlamaktadır. Görsel algının sağlanabilmesi için gerekli olan aydınlığın, nicelik ve nitelik özelliklerinin uygun bir biçimde oluşturulması gereği; bu özelliklerin açıklanması uygun görülmüştür.

\subsubsection{Aydınlığın Niceliği}

"Aydınlığın nicelik boyutu 'aydınlık düzeyi' kavramı ile anlatılmaktadır. Bu kavram aydınlığın azlığı-çokluğu ile ilgilidir. Simgesi $E$, birimi $\mathrm{Im} / \mathrm{m}^{2}$ olan aydınlık düzeyi ölçülebilen ancak görünmeyen bir büyüklüktür. Işık ölçümsel büyüklükler arasında görünen tek büyüklük 'ışıklılıktır (L).' Aydınlık düzey $(\mathrm{E})$ ile yüzeyin yansıma çarpanına (r) bağlı olan ışıklılık görünürlükle ilgilidir ( $L=E x r)$; yani ışıkıılıkları olan nesneler görülür. Görsel algılamadan söz edilebilmesi için, baktığımız alanda renk ve ışıklılık karşıtlıkları olması gerekmektedir" (Sirel, 1992, s.2). Bu bakımdan aydınlığın niceliğini belirlemede öncelikle aydınlık çoğunluğunu belirlemek gerekmektedir. Bununla birlikte konfor koşullarının sağlanması için kamaşma kontrolü yapılmalı ve adaptasyon sağlanmalıdır.

Işıklılıkların uygun olmayan dağılımları ya da aşırı karşıtlıkları sonucu yetersizlik ve konforsuzluk kamaşması olarak adlandırılan iki tür kamaşma meydana gelmektedir. Yetersizlik kamaşmasında ışık kaynağının parııtısı ve alanı ile doğru, kaynakla görsel hedef arasındaki açı ile ters orantılı saçılma söz konusudur. Yetersizlik kamaşmasının engellenebilmesi için kaynağın açısal sapması değiştirilebilmekte, kaynağın parıltısı azaltılabilmekte veya maskelenebilmekte, görsel hedefteki aydınlık düzeyi yükseltilebilmekte, yüksek yansıtıcı özelliği olan yüzeylerden kaçınılabilmektedir. Konforsuzluk kamaşması görsel algıyı doğrudan etkilemese de hoş olmayan hissiyata neden olmaktadır (Ritter, Ritter, 2011, s.48).

Müzelerin sergileme mekânlarında eserlerin görülebilmesi için gerekli olan aydınlık düzeyini belirlemek, bu eserlerin özelliklerini belirlemekle mümkün olmaktadır. Bu durum sergilenecek olan eserlerde meydana gelebilecek zararlı etkileri de en aza indirgemek için gereklidir. Uluslararası Müzeler Konseyi tarafından belirlenen, farklı nesneler için sağlanması gereken aydınlık düzeyi değerlerinin üst sınırları Çizelge 1'de verilmiştir.

Çizelge 1: Müze nesnelerinin türüne göre izin verilen aydınlık düzeyi üst sınırları (Sirel,1990, s.2).

\begin{tabular}{|c|c|}
\hline Nesne & $\begin{array}{l}\text { İzin Verilen Aydınlığın Üst } \\
\text { Sınırı }(I \mathrm{~m} / \mathrm{m})^{2}\end{array}$ \\
\hline Eski el yazıları, renkli minyatürler, ortaçağ resim kitapları vb. & 30 \\
\hline $\begin{array}{c}\text { Baskılar, desenler, suluboyalar, eski kumaşlar, pullar, eski halılar, } \\
\text { minyatürler, organik doğa bilimi örnekleri vb. }\end{array}$ & 50 \\
\hline $\begin{array}{c}\text { Doğal deri, boynuz, fildişi, ahşap, yağlıboyalar, laklar, tutkallı boylara vb. } \\
\text { Taş, metal, seramik, cam, değerli taşlar, emaylar vb. }\end{array}$ & $\begin{array}{l}150-180 \\
300-500\end{array}$ \\
\hline
\end{tabular}

İnsan gözünün farklı aydınlık düzeylerine uyabilme kabiliyeti gözün 'adaptasyon'u olarak açıklanmaktadır. Karanlık ve aydınlık adaptasyonu olmak üzere iki türlü adaptasyon bulunmaktadır. Karanlık adaptasyonu, aydınlık bir yerden karanlık bir yere geçişteki; aydınlık adaptasyonu da karanlık bir yerden aydınlık bir yere geçişteki durumdur. Bu iki farklı durum, sergileme mekanlarındaki kullanıcıların mekandaki nesneleri algılamasında önem taşımaktadır. Sergileme mekanlarında adaptasyonun sağlanabilmesi için aydınlık düzeyleri arasındaki kontrast azaltılmalı, ışık kaynaklarının 
mekân içindeki konumları bakış açısının dışında olmalıdır. Genellikle tercih edilen yöntem olan, aydınlık seviyelerinin kademeli olarak düşürülüp yükseltilmesi iyi görme koşullarının sağlanmasına da olanak vermektedir.

\subsubsection{Aydınlığın Niteliği}

Aydınlığın niteliğinin belirlenmesinde dikkat edilmesi gereken unsurlar; ışığın renksel özelliği, ışık akısının doğrultusal yapısı, ışığın yansıma-geçirme özellikleri ve oluşan gölgelerin niteliğidir.

- Aydınlığı oluşturan ışığın renksel özelliği: Aydınlatmada renk, ışığın ve yüzeylerin rengi olmak üzere iki ayrı şekilde ele alınmaktadır. Işığın rengi onu oluşturan elektromanyetik ışınımın dalga boyuna bağlıdır. Işık; dar bir dalga boyu aralığında oluşuyorsa 'tek renkli ışık'; gün ışığında olduğu gibi, tüm görünür ışınım dalga boylarını içeriyorsa 'beyaz ışık' olarak anılmaktadır. Üzerine düşen ışığı, dalga boyu yapısında bir değişikliğe uğratmadan yansıtan yüzeyler 'tarafsız yansıtmalı yüzey' olarak anılmaktadır. Yüzeylerin çoğu üzerine düşen ışığın bir bölümünü emer ve diğerlerini yansıtır. Yansıyan ışığın dalga boyları ise yüzeyin rengini oluşturur (Özdeniz, 1996, s.40). Müze sergi mekânlarında ziyaretçiye sunulan eserlerin, nesnelerin gerçek renkleriyle algılanabilmesi önemli olduğu için, renksel geriverimi yüksek olan aydınlatma kaynaklarının seçimine dikkat edilmelidir (Şekil 1).

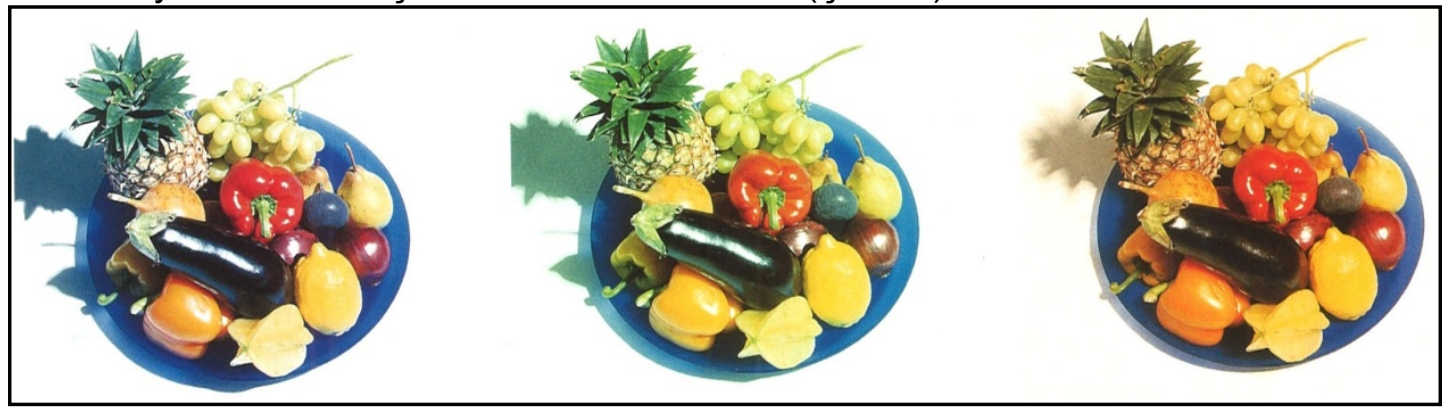

Şekil 1: Farklı ı̧ık kaynaklarıyla aydınlatılmış nesnelerin görünen renkleri (Turner, 1998, s.39).

- Aydınlığı oluşturan ışık akısının doğrultusal yapısı: Işık kaynağından çıkan ve normal gözün spektral duyarlık eğrisine göre değerlendirilen enerji akısına ışık kaynağının akısı adı verilmektedir (Küçükdoğu, 2010, s.10). Aydınlığı oluşturan ışık akısının doğrultusal yapısını Dokuzer Öztürk "bir düzlem üzerine düşen ışık akısı,

a. Tek bir doğrultudan ya da birbiri ile ufak açılar yapan bir doğrultu demetinden gelebilir

b. Birçok ya da sonsuz doğrultudan gelebilir.

c. Her iki durum, yani 'a' ile ' $b$ ', değişen oranlarda birlikte olabilir.

'a' durumuna doğrultulu ışık alanı, ' $b$ ' durumuna doğrultusuz ya da yayınık ışık alanı, 'c' durumuna da baskın doğrultulu ışık alanı denir" (Dokuzer Öztürk, 1992, s.5-7) şeklinde açıklamaktadır. İç mekânlarda çok özel durumlar dışında ışık alanının yapısı tavan, duvar gibi yüzeylerde ışığın yansıması nedeniyle yayınık ya da baskın doğrultuludur (Sirel, 1992, s.4). Daha açık bir deyişle; "bir yüzeye düşen ışık, tek bir doğrultudan, birkaç doğrultudan, sonsuz doğrultudan gelebilir ve bunların ikişer, üçer, değişik oranlardaki karışımlarına göre, doğrultulu, yayınık, baskın doğrultulu vb. yapıda olabilir. Işığın (ya da ışık alanının) doğrultusal yapısı, görsel algılama konusunun özelliklerine bağlı olarak değişik biçimlerde oluşturulmalıdır" (Ünver, 1996, s.66).

- Aydınlığı oluşturan ışığın yansıması/geçmesi: Işığın çarptığı yüzeyde yansıtma, yutma ve geçirme olmak üzere üç davranış ortaya çıkmaktadır. Kullanılan 
malzemenin ışık yansıtma biçimlerine bağlı olarak düzgün yansıma, yayınık yansıma, izotrop yayınık yansıma ve karışık yansıma olmak üzere dört biçimden bahsedilebilir" (Fitoz, 2011). Düzgün yansıma yapan parlak yüzeylerde görünürlüğü olmayan yüzeylerde, yüzey sınırı içindeki başka yüzey ve/veya nesnelerin görüntülerinin algılanması; yayınık yansıma yapan yüzeylerde, parlaklık arttıkça yüzey ve/veya nesnelerin görüntülerin belirginleşme olması, parlaklık azaldıkça yüzeyin özelliklerinin görünümünde artı̧̧ olması; izotrop yayınık yansıma yapan mat yüzeylerde ışığın tüm doğrultulara yayılması; karışık yansıma yapan yüzeylerde ise hem kendine hem de çevredeki nesnelere ait görüntülerin yansıtılması söz konusudur (Ünver, 1996, s.66).

- Aydınlığı oluşan gölgelerin niteliği: Saydam olmayan bir cisim tarafından ışığın engellenmesiyle ışıklı yerde oluşan karanlık gölge olarak adlandırılmaktadır (İmert, 2010, s.26). Aydınlığı oluşturan ışık akısının doğrultusal yapısı ile gölge niteliği doğrudan ilişkilidir. İç mekânlarda ışık kaynağı ile nesne, nesne ile gölge atılan yüzey arasındaki uzaklığa bağlı olarak, az ya da çok yumuşak, az ya da çok sert gölgeler elde edilmektedir (Sirel, 1992, s.5). Cisimlerin sahip oldukları doku ve detaylar ancak gölge oluşumunun desteği ile canlı ve etkili görünmektedir (Şekil 2).

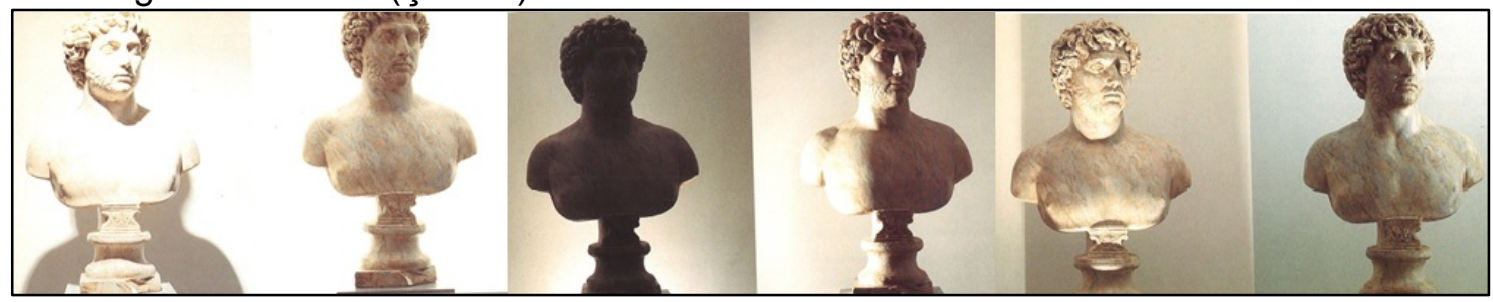

Şekil 2: Işığın doğrultusal yapısına bağlı olarak oluşturulmuş gölgeler (Turner,1998, s.40).

\subsubsection{Sergileme Mekânlarında Aydınlatmanın Sebep Olduğu Bozulmalar}

Müzelerde sergilenen eserlerin aydınlatılmasında en önemli unsur ziyaretçinin sunulanı algılayabilmesidir. Ancak, bu amaç yerine getirilirken eserlerde aydınlatma sebebi ile meydana gelebilecek bozulmaların en aza indirgenmesi ve böylece eserlerin korunarak geleceğe aktarılabilmesi de gerekmektedir. Eserlerin üzerine yönlendirilen ışık kaynakları, farklı oranlarda; mor ötesi ışınımları (Ultraviolet Radiation, UV), görünür ışınımları (Visible Radiation, V), ısıl ışınımları (kızı ötesi) (Infrared Radiation, IR) yayımlamaktadırlar. Bu sebeple zararlar hemen algılanamasa bile, eserlerde aydınlatma sebebi ile ciddi bozulmalar meydana gelmektedir.

\subsubsection{Morötesi Işınımlar (UV)}

Ultraviyole olarak da bilinen bu ışınımlar, "elektromanyetik spektrumda $\mathrm{X}$ ışınları ile görünür ışınlar arasında (200 nm-400 nm) yer almaktadır. Görünür ışınlardan UV ışınlarına doğru gidildikçe dalga boyu küçülmekte, enerji miktarı ve frekansı artmaktadır. Bir ışının dalga boyunun küçülmesi ve dolayısıyla enerjisinin artması sonucunda yüzeye nüfuz etme kabiliyeti de artmaktadır" (Karahan vd., 2007, s.250). Böylece nesneler üzerinde kimyasal bozulmalara, yıpranmalara neden olmaktadırlar. Kâğıdın sararması ve direncinin azalması, zamk ve verniklerinin solması, dokumaların solması ve liflerinin zayıflayıp kopması bu yıpranmalara örnek olarak gösterilebilir. Yıpranma oranları nesne özelliklerine bağlı olarak değişirken, yıpranmanın etkisi büyüyen dalga boyuna göre logaritmik olarak azalmaktadır. Sonuç olarak bazı nesneler özelliklerine bağlı olarak birkaç hafta içinde gözle görülebilir biçimde solarken kimilerinde aynı süreç çok daha uzun bir zamana yayılmaktadır (Sirel, 1999, s.113114). Bayer (2007, s.14)'e göre; bu ışınımların zararlarından korunabilmek için görünür ışınımlara saydam, görünmez ışınımlara opak süzgeçler (film, cam) kullanılmalıdır ya 
da ışık kaynaklarından çıkan ışınımlar, morötesi ışınımları yutan (çok az yansıtan) titanyum dioksit, kurşun dioksit ve çinko oksit gibi boyların sürülmüş olduğu duvar, tavan vb. yüzeylerden yansıtılarak nesne üzerine yönlendirilmelidir. Burada unutulmaması gereken nokta, süzgeçlerin kullanımı ile ışığın niteliğinin değişebileceğidir.

\subsubsection{Görünür Işınımlar (V)}

"Gözü etkileyerek görme olayını doğuran ışınların hepsine birden ışık denir. Yani ışık; görünür elektromanyetik ışınım ve bu ışınımın oluşturduğu duyumdur" (Demircioğlu Yıldız, Yılmaz, 2005, s.117). İnsan için görünür ışınımların dalga boyu 400 nm-700 nm arasında bulunmaktadır. Bu aralıktaki dalgalar, gök kuşağında oluşan renkler olarak da görülebilmektedir. Buradaki her bir renk farklı bir dalga boyunu karşılamaktadır. Kırmızı renge karşılık gelen dalga, görünür bölgenin en uzun dalga boyuna karşılık gelirken, mor en kısa dalga boylarına karşılık gelmektedir. Görünür bölgedeki bütün dalgalar birlikte beyaz ışığı oluşturmaktadır (Url-3). Gözde duyulanma yaratan görünür ışınımların da 500 nm'ye kadar olan büyük bir bölümü, diğer ışınımlar gibi, el yazmaları, baskılar, halılar, renkli minyatürler vb. duyarlı nesneleri yıpratmaktadır (Sirel, 1999, s.113-114).

\subsubsection{Kızılötesi Işınımlar (IR)}

İnfrared ışınımlar olarak da bilinen ısıl ışınımlar, elektromanyetik spektrumda mikrodalga ışınları ile görünür ışınlar arasında $(1 \mathrm{~mm}-750 \mathrm{~nm})$ yer almaktadır. Görünür ışınlardan kızılötesi ışınlarına doğru gidildikçe dalga boyu büyümekte, enerji miktarı ve frekansı azalmaktadır. Bu tür ışınımlar; uzak kızılötesi, orta kızılötesi ve yakın kızılötesi olmak üzere üç ana kategoride incelenir. Yakın kızılötesi ışınımı, görünür bölge ışınımının dalga boyuna çok yakın iken, uzak kızılötesi ışınımı, mikrodalga bölgesine daha yakındır. Kızılötesi ışınımları nesneler üzerinde çatlama, yarılma, büzülme ve biçim değiştirme gibi fiziksel bozulmalara neden olabilmektedir. Sergilenen eserlerin aydınlatılmasında kullanılan lamba ışığı ısıl ışınımları içereceğinden "ışık, nesne üzerine doğrudan gönderilmemeli; yani nesnenin kendini aydınlatan ışık kaynağını görmemesi sağlanmalıdır. Nesne lambayı görmek zorunda ise nesne ile lamba arasına, ıSı ışınımlarını önleyen bir süzgeç (filtre) konmalı ya da ısı ışınımları dağıtan dikroik yansıtıcılı aygıtlar kullanılmalıdır. Her iki koşulda da, iyi bir havalandırma sistemi gereklidir" (Bayer, 2007, s.13).

\section{Araştırma Materyali ve Metod}

Gerçekleştirilen araştırma doğrultusunda, müzelerin koruma, sergileme ve eğitim işlevlerini en iyi şekilde yerine getirmesine destek sağlayacak görsel konfor koşullarında önemli bir etkisi olan aydınlatma düzenleri, SALT Galata yapısı özelinde yerinde gözlem yapılarak incelenmiştir. Belirtilen yapı içerisindeki Osmanlı Bankası Müzesi sürekli sergileme ve süreli sergileme mekânları örnek olay tarama modeline uygun olarak incelenmiştir.

\subsection{Araştırma Materyali: Osmanlı Bankası Müzesi SALT Galata}

İstanbul'un Beyoğlu ilçesi sınırlarındaki Galata semtinin, günümüzde Bankalar Caddesi olarak da bilinen Voyvoda Caddesi'nde yer alan Osmanlı Bankası, Türkiye'de özel bir banka tarafından kurulan ilk müze olma niteliğini taşımaktadır. Kırım Savaşı (18531856) sonrasında mali durumu kötüleşen imparatorluğun modernleşme için geliştirilen reform programına kamu finansmanı yönetimi ile ilgili değişikliklerin eklenmiş ve 1863 yılında Bank-ı Osmani-i Şahane kurulmuştur. 1884 yılında Osmanlı Bankası tarafından 'Osmanlı Imparatorluğu Reji Idaresi'nin kurulması ile şubelerle iş birliği yapılarak, her iki 
kuruluşun merkez servislerini birleştirmek üzere, İstanbul'un iş merkezinde yapı topluluğu inşaatına başlanmıştır. Planlar, 19.yüzyıl sonunda İstanbul'da faaliyet göstermiş ve pek çok kamu yapısının inşa sorumluluğunu almış Fransız mimar Alexandre Vallaury tarafından çizilmiştir. 1892 yılında bankaya ayrılan kısmın açılışına kadar banka faaliyetleri St. Pierre Hanı'nda sürdürülmüştür (Autheman, 1988, s.13-14). Doğu-batı doğrultulu ve kompleks düzende iki binanın bir bütün olarak algılandığı Osmanlı Bankası Genel Müdürlüğü Binası'nın, içeriden de birbirlerinin özelliklerini tekrar eden iki bölümden oluştuğu görülmektedir (Şekil 3). Merkez Bankası'nın 1925 yııında satın alışından sonra birtakım değişiklikler yapıldığı için batı kısmında özgünlüğünü epeyce yitirmiş olan yapının, kuzey cephesi neorönesans ve neoklasik üslupta düzenlenmiştir (Aktemur, 2005, s.6).

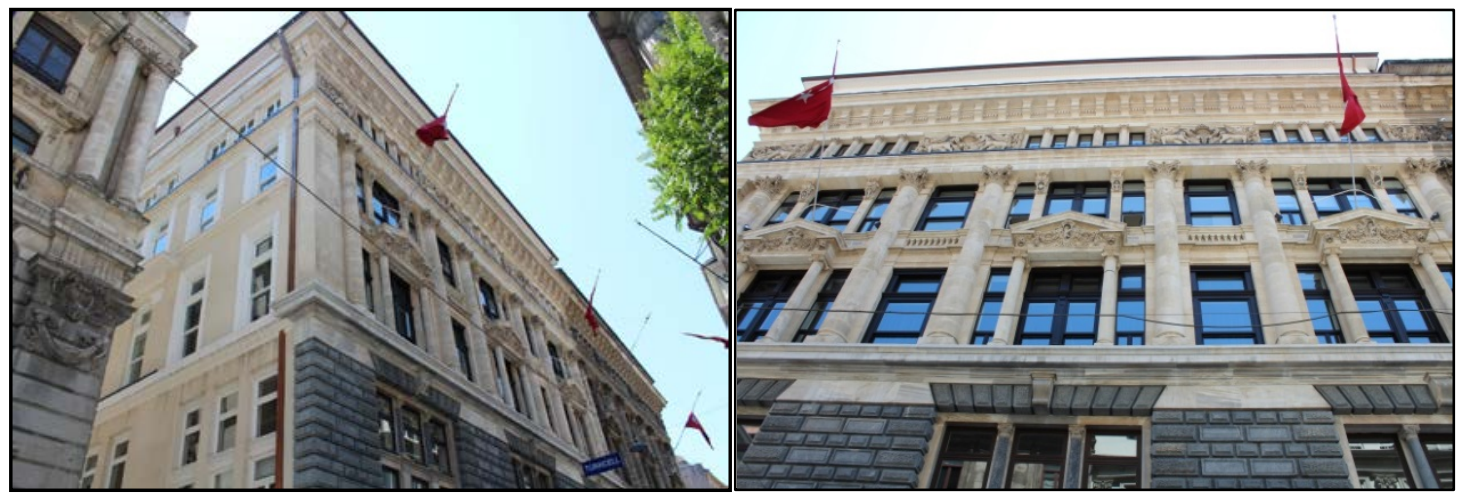

Şekil 3: SALT Galata yapısı (Yazar Kişisel Fotoğraf Arşivi).

Alexandre Vallaury tarafından çizilen 1890 tarihli planlara göre yapının bodrum katında mahzen, depo ve ahırlar bulunmaktadır. Zeminin altındaki katta, Londra'nın en ünlü kasa imalatçısı Samuel Charwood'a sipariş edilen ve adını dönemin 20 kuruşluk sikkelerinden alan Mecidiye Kasası ile yemekhane; zemin katında ise şubeyle ilişkili mekânlar konumlanmıştır. Birinci katta genel müdürün özel ve makam odalarının yanı sıra, sekreter ve tercümanların büroları; ikinci katta muhasebe şefi ve servisi, hükümet nazırı ve müfettişlik odaları; tavan arasında ise iaşe dairesi, arşiv servisi ve hizmetli odaları düşünülmüştür (Şentürk vd., 2003, s.8-9). Her öğesinin, ait olduğu dönemin siyaseti, ekonomisi, toplumu hatta gündelik yaşamı ve kültürü bağlamında incelendiği bir mekân olan Osmanlı Bankası Müzesi, yalnızca kurumun öyküsünü aktarmakla kalmayıp, bir dönemin yaşam temsilini de sunmaktadır.

100 yılı aşkın bir süreyi geride bırakan bina, Osmanlı Bankası tarafından Tarih Vakfı iş birliği ile 1997 yılında kurulmuş olan ve 2001 yılından itibaren Garanti Bankası çatısı altında faaliyet gösteren Osmanlı Bankası Arşiv ve Araştırma Merkezi faaliyetine başlamıştır. Osmanlı Bankası Müzesi bu merkez bünyesinde yer almaktadır. Osmanlı Bankası Arşivi' nin tasnif edilmesinin yanı sıra, sözlü tarih çalışmaları, yayın, sergi, belgesel, kolokyum, yarışma ve benzeri projelere imza atan merkez, 2010 yılı itibariyle etkinliklerine son vererek Garanti Galeri ve Platform Garanti Güncel Sanat Merkezi ile SALT ismi altında birleşmiştir. SALT, güncel sanat, ekonomik ve sosyal tarih, mimarlık, tasarım ve şehircilik alanlarında araştırma, sergi, söyleşi, konferans, atölye çalışmaları, yorumlama programları, film gösterimleri ve yayınlar yapmaktadır (Url-4). 
Çizelge 2: SALT Galata iç mekânlarından örnekler (Yazar Kişisel Fotoğraf Arşivi).

SALT Araştırma grup çalışma alanları ve orta avlu.
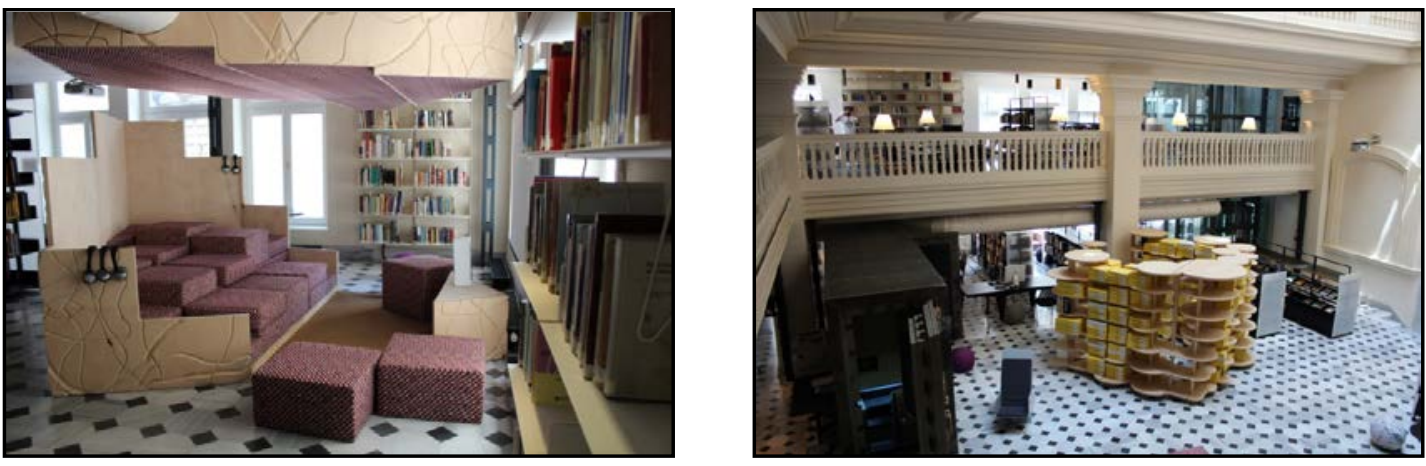

SALT Dükkân.
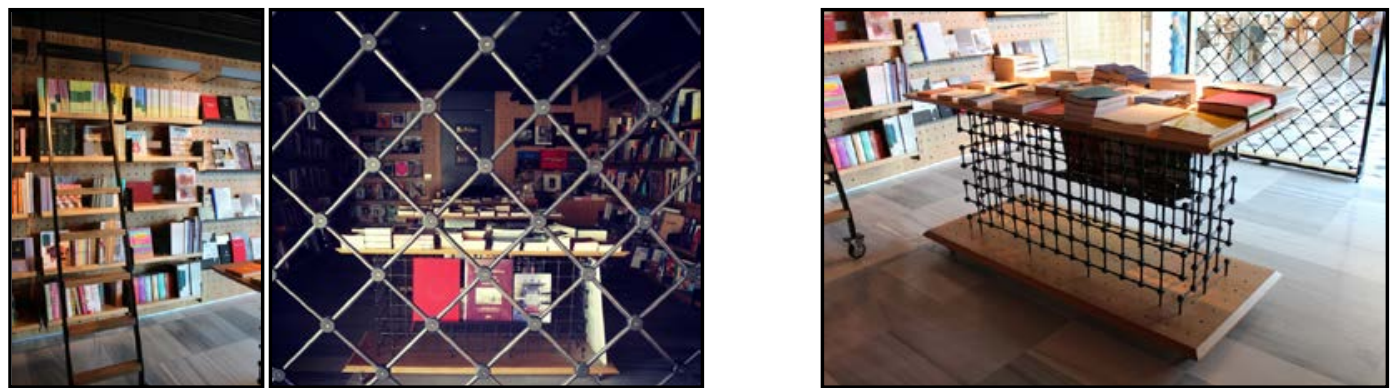

Ca'd'Oro Restoran/ Hüseyin Rahmi Alptekin'in kişisel kitaplığı ve Autoban Tasarım Ofisi tarafından tasarlanan kullanıcı hizmet üniteleri.
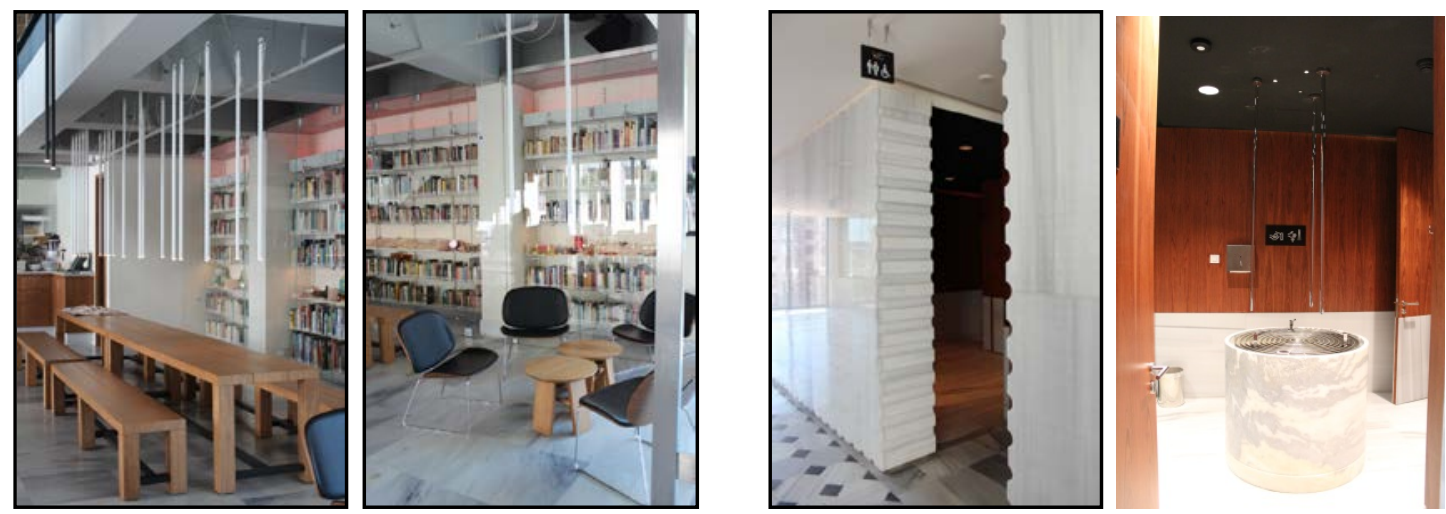

2011 yılında yeniden işlevlendirme sonunda kapılarını tekrar ziyaretçilere açan SALT Galata'nın projesi Mimarlar Tasarım/Han Tümertekin tarafından yürütülmüştür. SALT'ın yeni ve deneysel yaşam ve çalışma alanlarını destekleyen anlayışı doğrultusunda, binaların iç mekânlarında altı ayrı tasarım ve mimari ofisi ile çalışılmıştır (Url-5). "SALT Galata, mimari çalışmalar kapsamında, binanın özgün karakterini ortaya koyacak biçimde eklerinden arındırılmış ve mekânsal kurgusu, çok katmanlı programın gereksinimlerine göre düzenlenmiştir" (Url-6). SALT Galata; kütüphanesi ve arşivi ile basılı ve dijital kaynakları erişime açan SALT Araştırma, 219 kişi kapasiteli Oditoryum, yeniden tasarlanan Osmanlı Bankası Müzesi, çok sayıda katılımcıyla çalışmaya 
elverişli Atölyeler, arşiv malzemelerini gün ışığına çıkaran Açık Arşiv, Kafe ve Restoran, Dükkân ve sergi alanlarını içermektedir (Çizelge 2).

\subsection{Metod}

Çalışmada Osmanlı Bankası'na ait müze mekânlardaki aydınlatma düzenlemelerine odaklanılmıştır. Bu odak dahilinde yapı içerisindeki sürekli ana sergi mekânları ile süreli sergi mekânı incelenmiştir.

Çalışma için seçilen araştırma; nicel araştırma yöntemlerinden örnek olay tarama modeli kullanılarak gerçekleştirilmiştir. Evrendeki belli bir ünitenin (birey, nesne, müze vb.) derinliğine ve genişliğine, kendisini ve çevresi ile olan ilişkilerini belirleyerek, o ünite hakkında bir yargıya varmayı amaçlayan tarama modeline örnek olay tarama modeli denilmektedir. Gözleme dayalı olarak gerçekleştirilen çalışmada sahadan veri toplarken katılımcı gözlem, veri toplama aracı tercih edilmiştir.

\section{Bulgular ve Değerlendirme}

\subsection{Osmanlı Bankası Müzesi Sürekli Sergileme Mekânına Ait Aydınlatma Uygulamaları}

Osmanlı Bankası'nın Bankalar Caddesi'ndeki eski Osmanlı Bankası genel müdürlük binasında Arşiv ve Araştırma Merkezi'nin bünyesinde 2002 yılında hayata geçirilen müzede; Osmanlı Bankası'nın faaliyet dönemi boyunca yaşanan önemli değişiklikler, gelişmeler ve krizler kronolojik olarak ele alınırken, aynı dönemin şube binaları ve müşterilerinin faaliyet alanları da vurgulanmaktadır (Url-7). "Müzenin ana sergileme alanının ortasında bulunan dört kasa dairesi, belirli tipteki belgeleri ayrıntılı şekilde sergilemek için kullanılmaktadır. İç içe geçiş yapılarıyla bizzat bir müze objesi olan dört kasada, bankanın muhasebe defterleri, müşteriler tarafından emanet edilen hisse senetleri ve tahvillerin yanı sıra, müşteri dosyaları, personel dosyaları ve kâğıt paralar sergilenmektedir (Şekil 4). Kasaların dışındaki mekânda ise ziyaretçilerin bizzat inceleyebilecekleri dosyalar, müşteri kartları, hisse senetleri ve fotoğraflar yer almaktadır" (Şentürk vd., 2003, s.19-20).
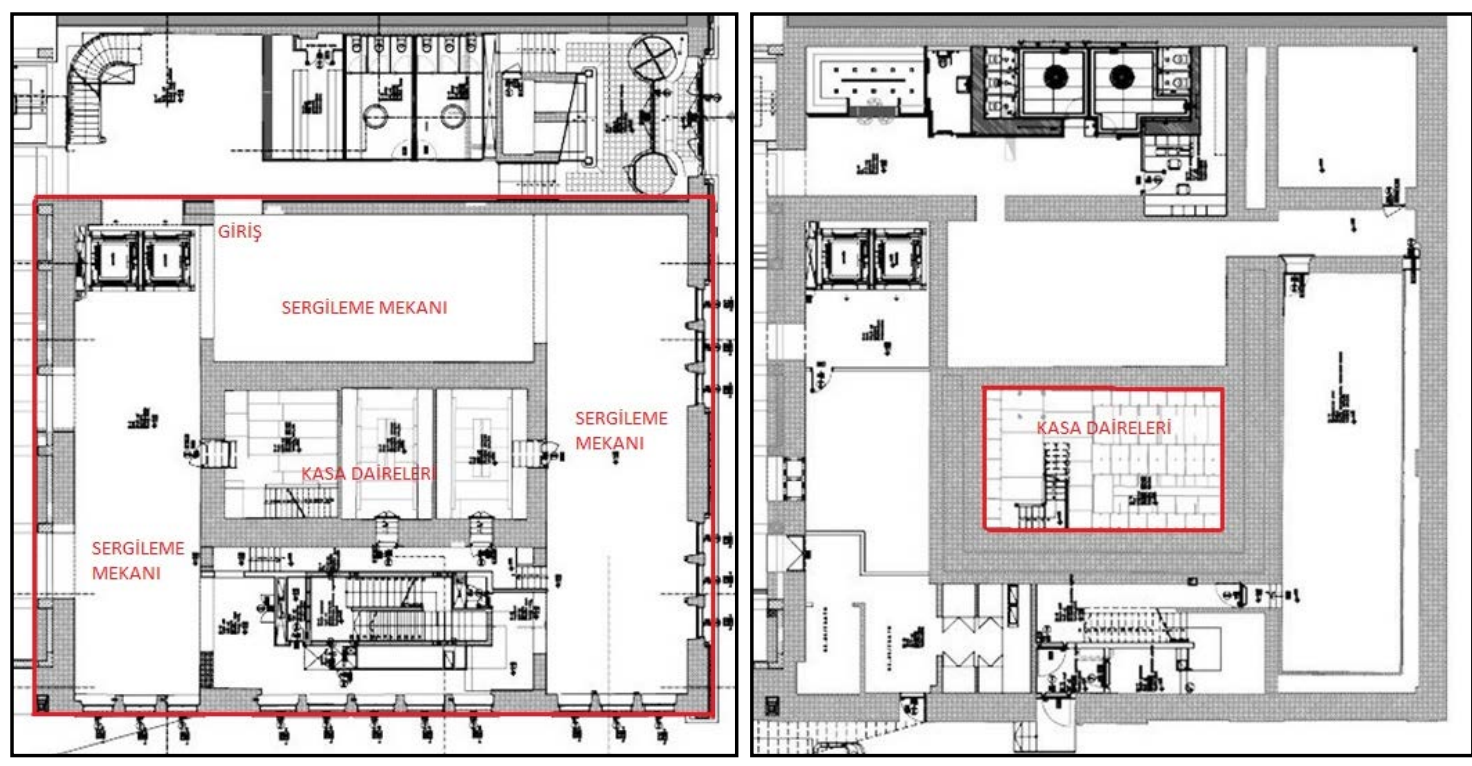

Şekil 4: Osmanlı Bankası Müzesi sürekli sergileme mekânı plan şeması - sürekli sergileme mekanları ve kasa daireleri (Url-5'den yararlanılarak yazar tarafından hazırlanmıştır). 
Arşiv ve konsept çalışmasını Prof. Dr. Edhem Eldem'in yürüttüğü müzenin tasarımını Bülent Erkmen yapmıştır. Sergileme birimlerinin tasarımı ve sergilemenin gerçekleştirilmesi çalışmaları Yeşim Bakırküre ile Ypsilon Tasarım tarafından gerçekleştirilmiştir (Şekil 5) (Url-7).
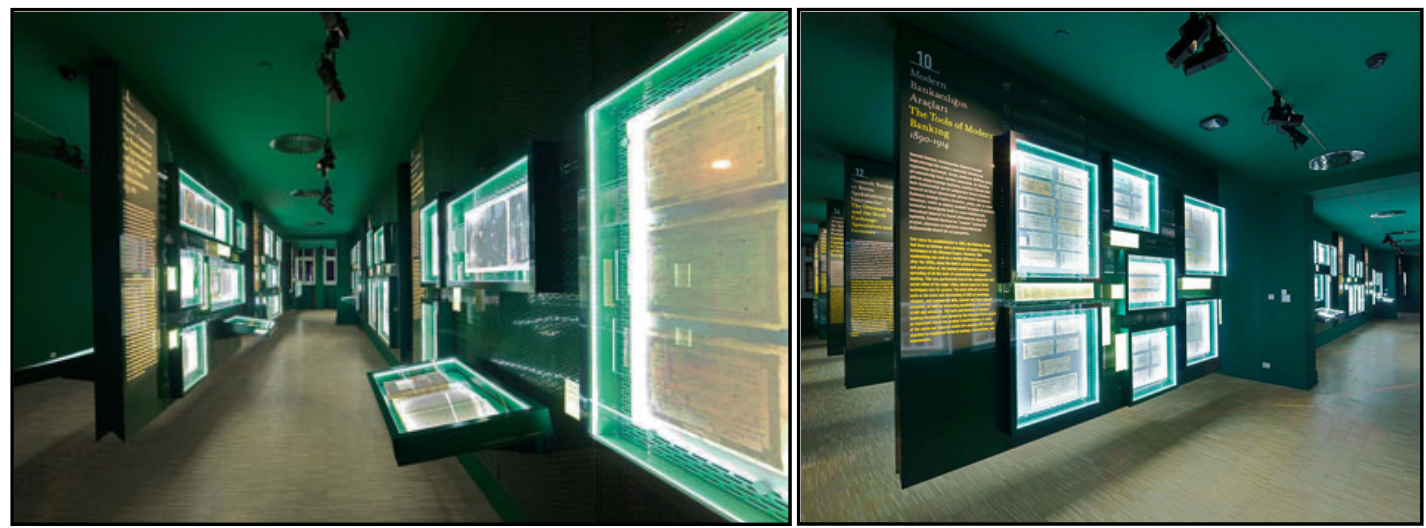

Şekil 5: Osmanlı Bankası Müzesi sürekli sergileme mekânından görünüş (Url-8).

"Bülent Erkmen'in Osmanlı Bankası Müzesi için yaptığı sergileme tasarımı, 2002'de 82.New York Art Directors Club'ın 'Merit' ödülünü kazanmıştır. Temel kavramı, mekânı çevreleyen tarihi yapı duvarları içindeki 'sarkıt duvarlar' olan sergileme tasarımında, sergilenenler havada duran bu 'duvarların' girintilerinde yer almakta ve aynı zamanda mekânın müze olma özelliği de göz önünde bulundurularak saklanmakta ve korunmaktadır (Şekil 6). Erkmen, havada sarkıt duvarlar kavramını şu şekilde açıklamaktadır: 'Önce, her şeyin havada asılı olduğu bir mekânda anıtsal bir mekân duygusu uyandırmak, yoğun ve etkileyici bir atmosfer oluşturmak, sonra sergilenenleri göstermek, 'sergileme'den etkilenmiş izleyiciyi 'sergilenen'le karşılaştırmak'" (Uyan Dur, 2011, s.167-168).
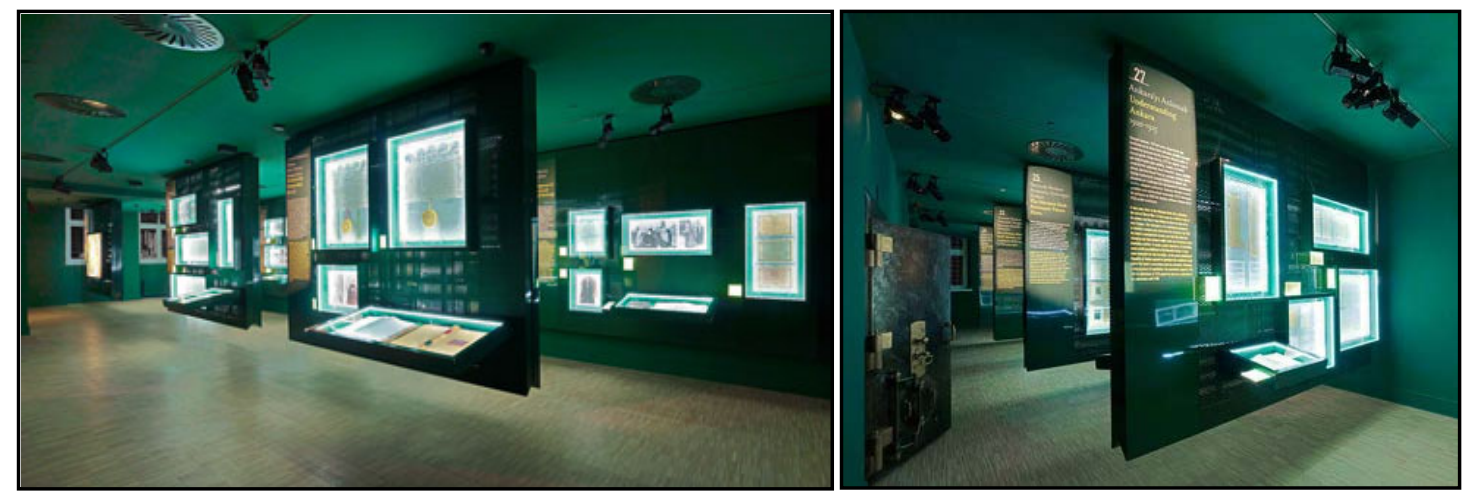

Şekil 6: Osmanlı Bankası Müzesi sergileme üniteleri-sarkıt duvarlar (Url-8).

\subsubsection{Aydınlatmanın Niceliği Bakımından Sürekli Sergileme Mekânı}

SALT Galata'nın -1. katında bulunan Osmanlı Bankası Müzesi'nin sürekli ana sergileme mekânı aydınlık düzeyi bakımından yapının işlevine uygun olarak tasarlanmış bir yapay aydınlatma düzeni ile aydınlatılmaktadır. İçeride sağlanan aydınlık düzeyinin dış çevreden etkilenmemesi için bu bölümdeki açıklıklar kontrol altına alınmıştır. İç mekânda sağlanan aydınlık düzeyi nesnelerin gerektiği gibi görülmesini sağlar niteliktedir. İncelenen mekânın tavan yüksekliği 3.1m'dir. Mekân içerisinde 12 adet $2.0 \mathrm{~m} \times 1.4 \mathrm{~m}, 5$ adet $2.5 \mathrm{mX1} .6 \mathrm{~m}$ boyutlarında pencereler bulunmaktadır. Ancak bu pencereler, çift tarafı film dışarıdan tek tarafı reflekte ile kaplanmış ve günışığının mekân içerisine girmesi engellenmiştir (Şekil 7). Böylece, 
kâğıt malzeme olan sergi nesneleri üzerinde doğal ışık kaynağından kaynaklanan zararlı ışınımlar sebebiyle meydana gelebilecek bozulmaların önüne geçilmeye çalışılmıştır.
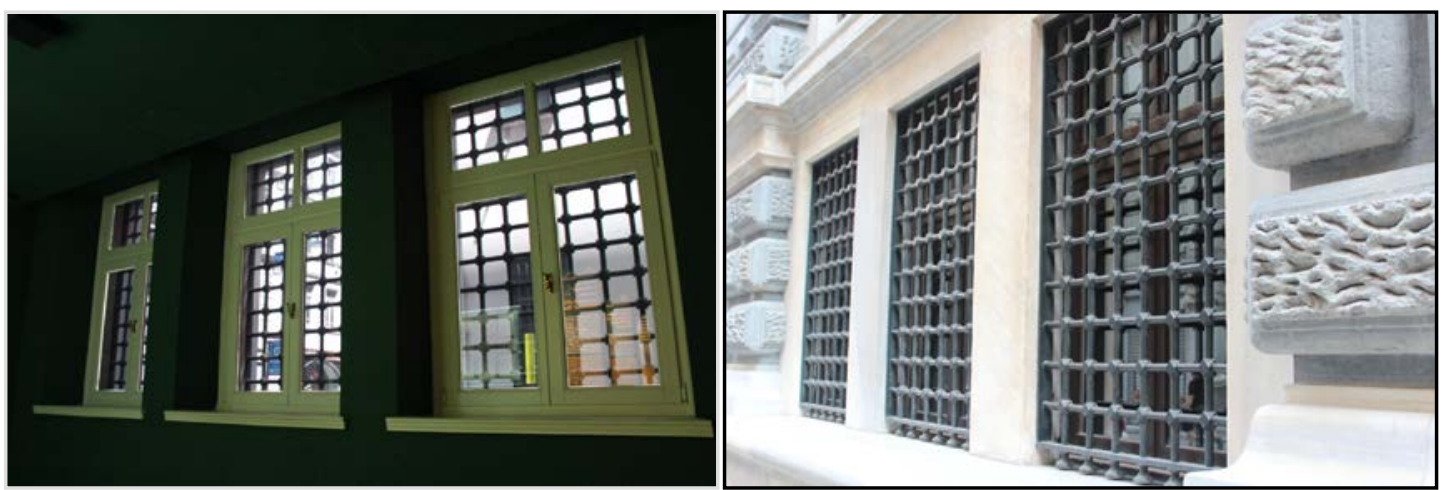

Şekil 7: Osmanlı Bankası Müzesi iç mekânda ve yapı cephesinde pencereler (Yazar Kişisel Fotoğraf Arşivi).

Sürekli ana sergileme mekânında istenilen aydınlatma düzeyine ulaşabilmek için iki farklı tipte lamba tercih edilmiştir. Sergileme mekânları için uygun olan bu lambalar; Panavision Lumiere DP-90-LED ve Erco CANTAX serisi lambalardan oluşmaktadır.

Müzenin sürekli ana sergileme mekânında Panavision Lumiere DP-90-LED armatürü kullanılmıştır (Şekil 8). İki parçadan oluşan, $18^{\circ} / 40^{\circ}-23^{\circ} / 42^{\circ}$ optik zoom özellikli modelleri de bulunan armatürün siyah, beyaz ve gri renkleri bulunmaktadır. Ortalama $1,5 \mathrm{~kg}$ ağırlığında, 260x195 mm boyutlarındadır ve ışık kaynağı 12-14,5V/90W gücünde halojen lambalardır. Bu lambalar raya yerleştirildikleri için istenildiğinde doğrultuları ve açıları değiştirilebilmektedir.

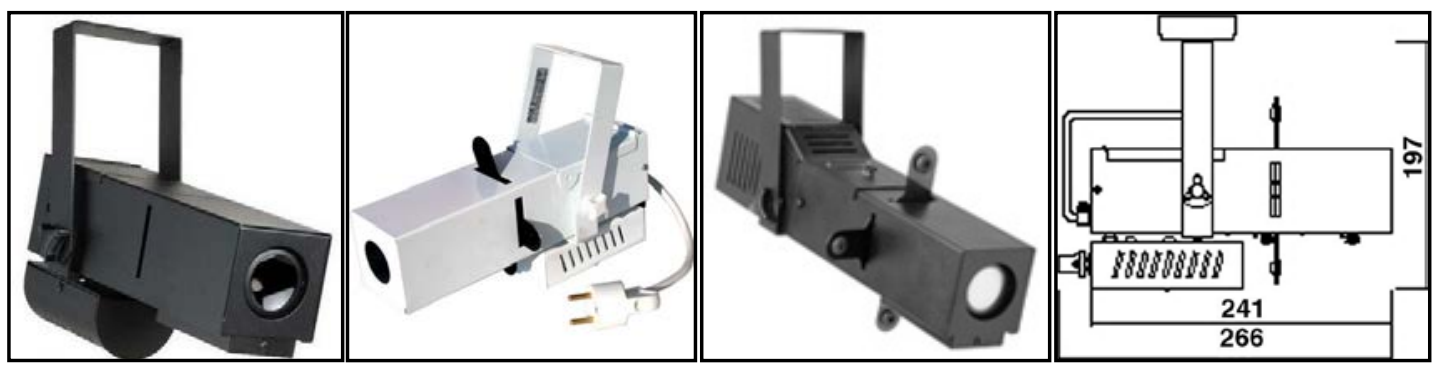

Şekil 8: Panavision Lumiere armatür modelleri ve DP75TED armatürüne ait teknik çizim

(Sırasıyla Url-9, Url-10, Url-11, Url-12).

Mekânda homojen bir aydınlatma sağlanmak istendiğinde ise, Erco'nun CANTAX model armatürü kullanılmaktadır (Şekil 9). Bu armatür, düşük voltajı halojen ve metal halide gibi lambalar ile uyumluluk sağlayabilmektedir. $200 \mathrm{~lm}-4920 \mathrm{~lm}$ aralığında ışık akısına sahip olan bu lambalar, noktasal ışık kaynakları olarak kullanılarak dikkati sergilenen nesnelere çekmektedirler. 

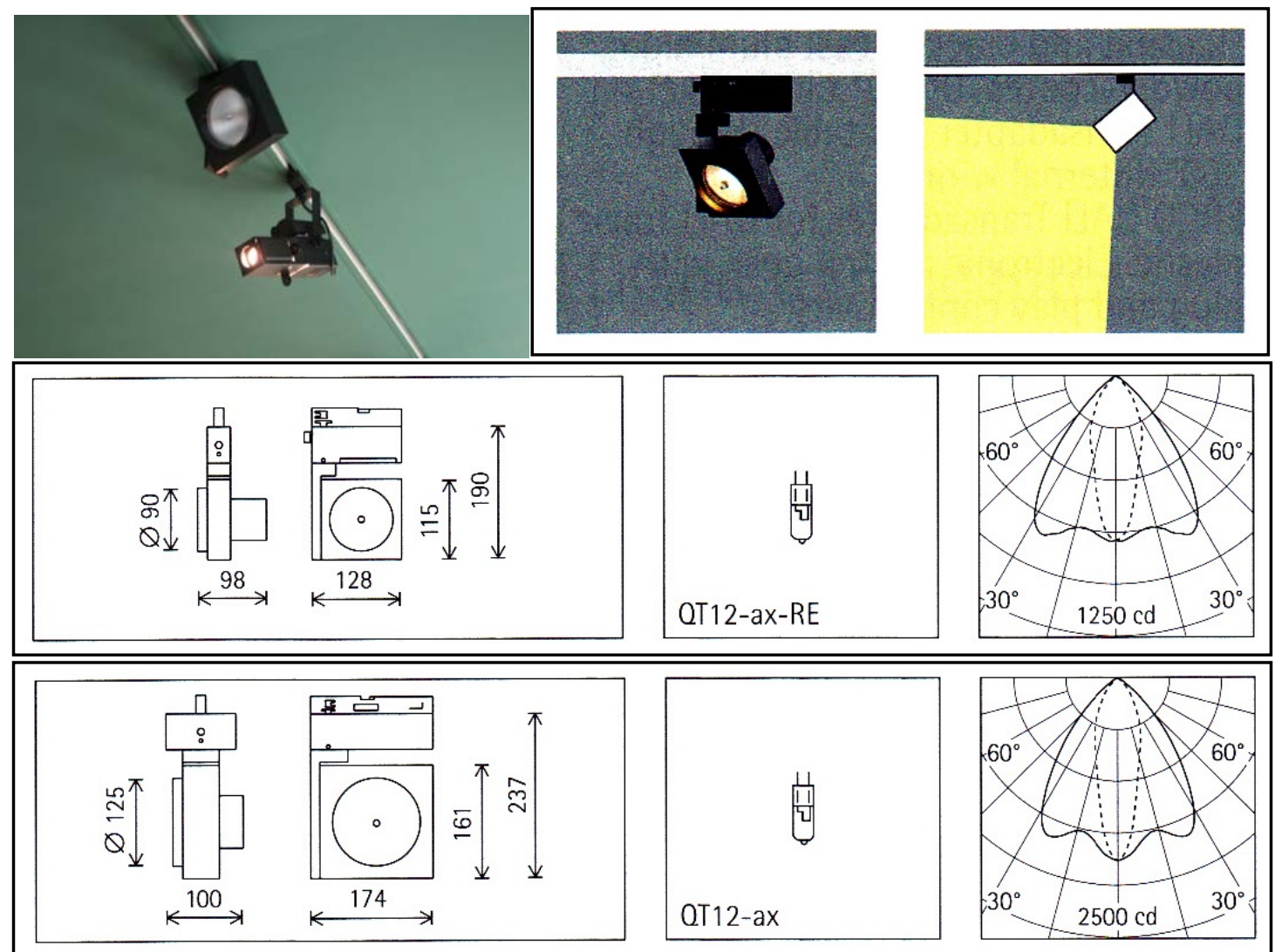

Şekil 9: Osmanlı Bankası Müzesi sürekli ana sergileme mekânı aydınlatma elemanları ve Erco Cantax modellerine ait teknik özellikler (Sırasıyla Yazar Kişisel Fotoğraf Arşivi, Erco 2012

Aydınlatma Ürün Kataloğu).

Kasa dairelerinde ise Erco markasının Jilly model, 12V/50W gücünde $2050 \mathrm{~lm}$ - 2700lm ray spot armatürleri ile yine Erco'ya ait flüoresanlı Optec model ürünler ağırlıklı olarak kullanılmıştır (Şekil 10-11). Mekânda kullanılan bölgelik aydınlatma elemanları aynı zamanda genel aydınlatmayı da sağlamaktadır. Verimliliği görsel konforla birleştiren bu lambalar, sanat galerileri ve müzelerdeki aydınlatma gereksinimlerini sağlayabilir özellikler taşımaktadırlar.

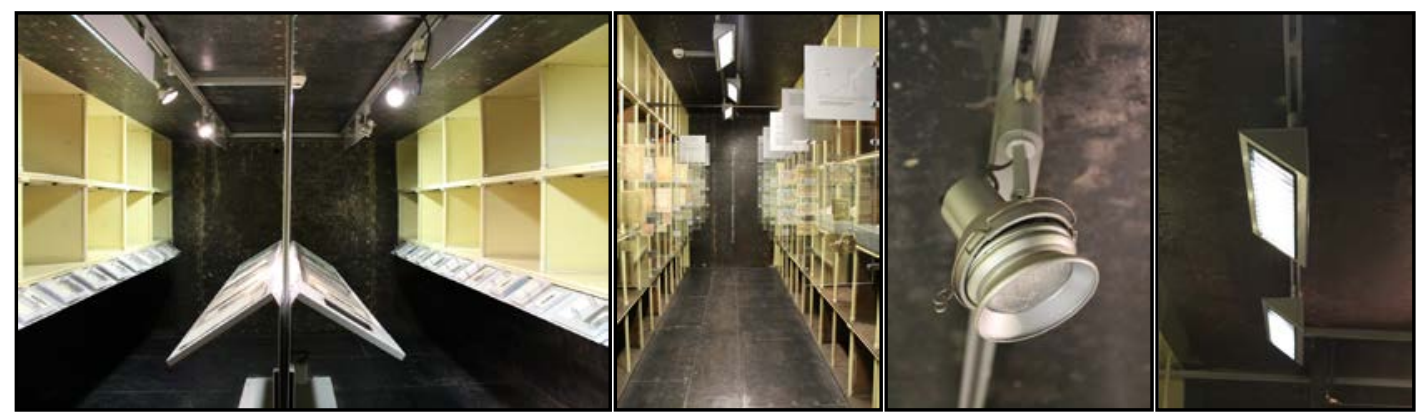

Şekil 10: Osmanlı Bankası Müzesi kasa daireleri sergileme üniteleri ve aydınlatma elemanları (Yazar Kişisel Fotoğraf Arşivi). 


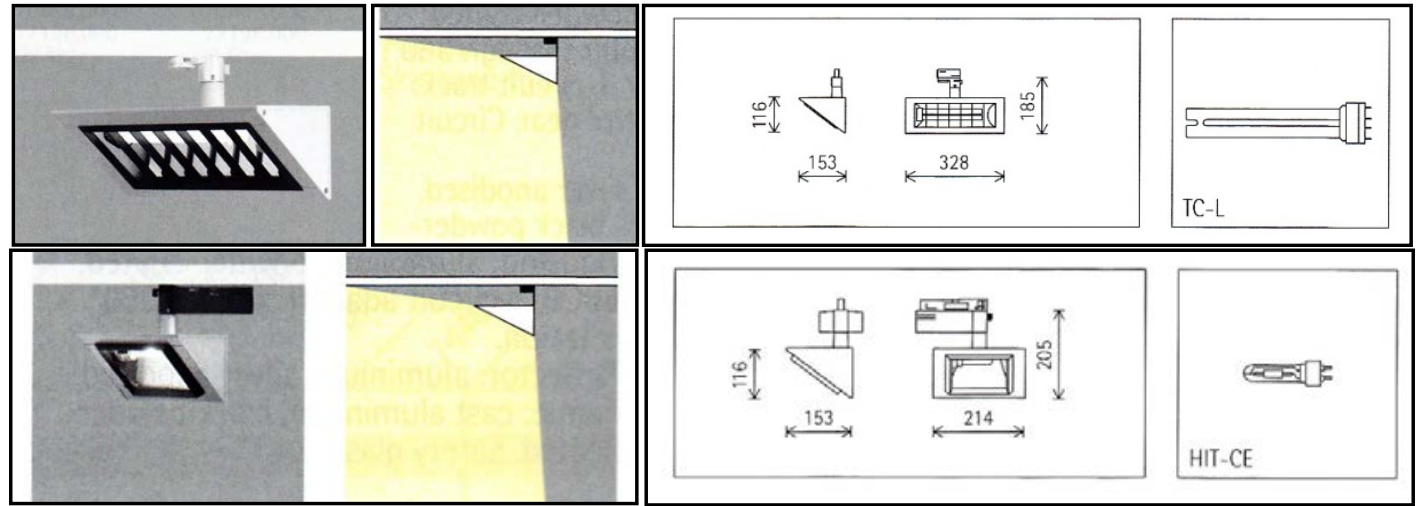

Şeki 11: Erco Optec Wallwasher modellerinden birkaçına ait teknik özellikler (Erco 2012 Aydınlatma Kataloğu).

Aydınlatmanın niceliği bakımından önemli olan diğer faktörler olan kamaşma kontrolü ve adaptasyonun sağlanması için mekânda yansıtıcı yüzeylerin kontrollü olarak yerleştirilmesine dikkat edilmelidir. Osmanlı Bankası Müzesi'nin kasa dairelerinin bir bölümünde, sergileme üniteleri aydınlatma elemanlarına dik olarak tasarlanmış olduğu için kamaşma engellenmiştir. Ancak ana mekânında kullanılan camlı vitrinlerde bu durum ziyaretçiyi rahatsız edecek, sergilenen nesnelerin okunmasını engelleyecek düzeydedir (Şekil 12).

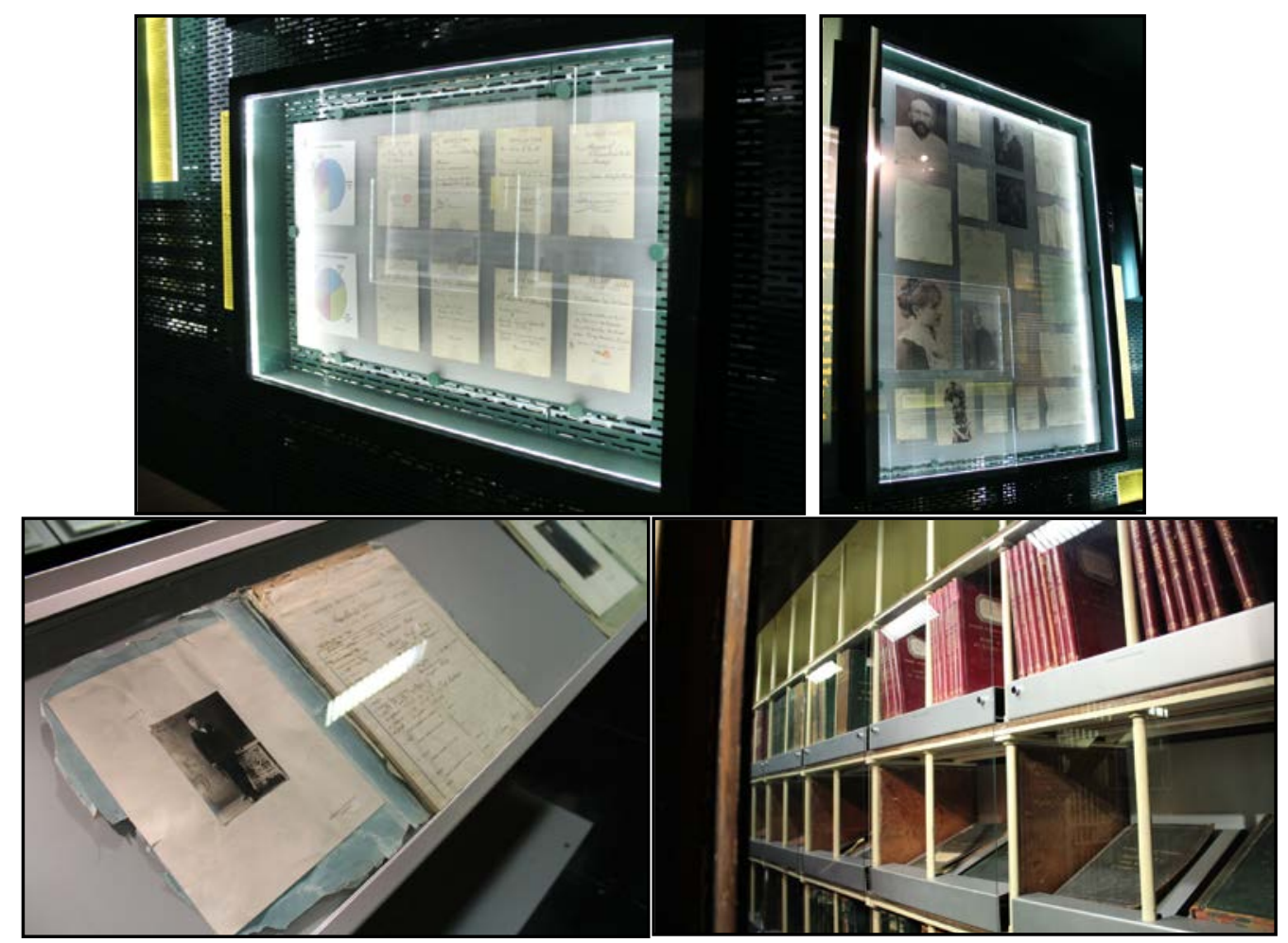

Şekil 12: Osmanlı Bankası Müzesi sergileme üniteleri üzerinde meydana gelen yansımalar (Yazar Kişisel Fotoğraf Arşivi).

Yüzeylerin yansıtıcılık özelliklerinin yüksek olması, aynı zamanda ziyaretçilerin görme adaptasyonu sürelerini de uzatmaktadır. Bu durum, aydınlık-karanlık arasındaki kontrastın yüksek olmasından kaynaklanmaktadır. Müze mekânlarının tamamında aydınlık-karanlık adaptasyonu için fonksiyona uygun aydınlık düzeyi sağlanmalıdır. 
Bununla birlikte mekanlar arasında kademeli aydınlık düzeyi değişiminin sağlanması da gerekmektedir.

\subsubsection{Aydınlatmanın Niteliği Bakımından Sürekli Sergileme Mekânı}

Osmanlı Bankası Müzesi'nin sürekli ana sergileme mekânı aydınlatmanın niteliği bakımından öncelikle kullanılan ışığın rengi özelinde incelenmiştir. Kasa dairelerinde Erco markasının Jilly model, $12 \mathrm{~V} / 50 \mathrm{~W}$ gücünde ray spot armatürleri $2700 \mathrm{~K}$ ile $4000 \mathrm{~K}$ arasında renk sıcaklığına sahiptirler. Bulundukları yere göre renk sıcaklıkları ayarlanabilen bu lambalar, renksel geriverim bakımından da oldukça yüksek değerlere sahiptirler. CRI 82 olan lambalar, nesneleri gerçeğe yakın olarak görmemizi sağlamaktadırlar. Işık akısının doğrultusal yapısı bakımından kullanılan lambaların downlight yani direkt aydınlatma sağlayacak şekilde aşağı yönlü olarak tasarlandıkları söylenebilir.

Ana sergileme mekânında kullanılan Erco'ya ait flüoresanlı Optec model ürünler ise Jilly serisinde olduğu gibi $2700 \mathrm{~K}$ ile $4000 \mathrm{~K}$ renk sıcaklığına sahiptirler ve renksel geriverimleri oldukça yüksektir. Bu tür lambalarda ışık, dar bir dalga boyu aralığında oluştuğu için tek renkli ışıkların tercih edildiği söylenebilir. Bu bakımdan müze mekânları için oldukça uygundurlar. Bu tür lambalar esnek lens alternatifleriyle ışık dağılımı bakımından daha geniş bir seçenek sunmaktadırlar. Bu özelliğin müze mekânında farklı boyutlardaki sanat nesnelerinin aydınlatılması bakımından da oldukça yararlı olduğu gözlemlenmiştir.

Müzede enerji sarfiyatı düşük, verimi yüksek olan direkt (dolaysız) aydınlatma tercih edilmiştir. Tüm aydınlatma aygıtları tavana gömülmüş raylı sistem üzerine yerleştirilmiştir (Şekil 13). Bu sistemde aydınlatma elemanlarında oluşan herhangi bir soruna rahatlıkla müdahale edilebilmekte, istenildiği takdirde intiyaca göre değişiklik yapılabilmektedir. Müzenin homojen aydınlatma biçimi kullanılması istenilen bölgelerinde yine bu sistemden yararlanılarak farklı aydınlatma elemanlarının kullanıldığı da gözlemlenen bir diğer unsurdur.
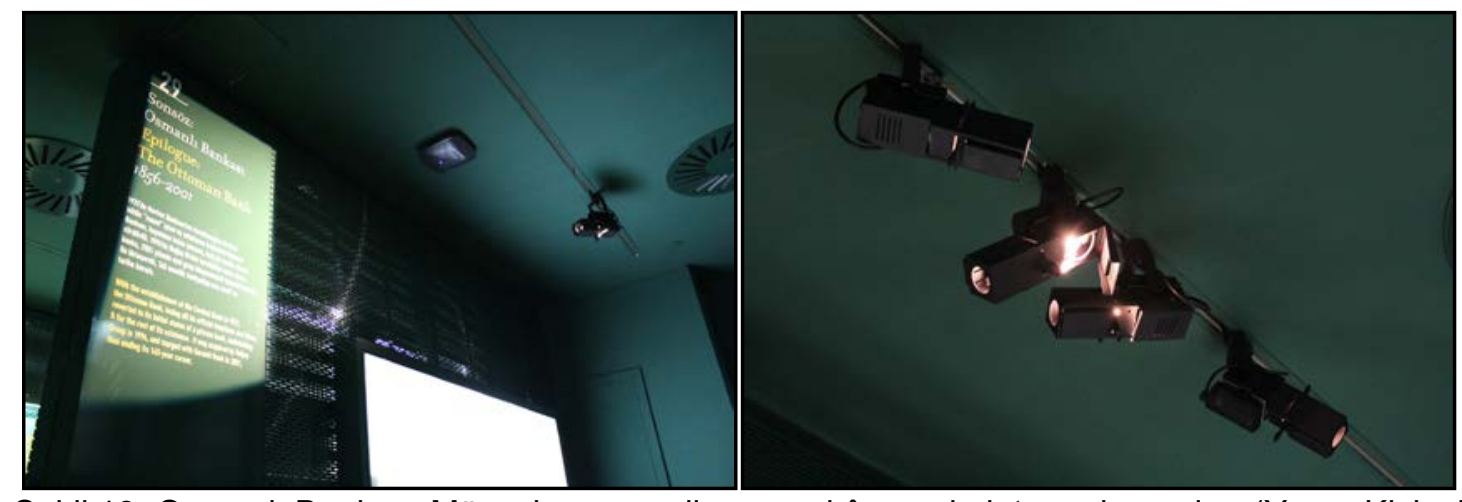

Şekil 13: Osmanlı Bankası Müzesi ana sergileme mekânı aydınlatma elemanları (Yazar Kişisel Fotoğraf Arşivi).

Müzede lambaların yerleştirildikleri konum bakımından direkt aydınlatma biçiminin tercih edilmesi, gölgelerin de yönünü belirlemiştir. Bu durumda zemin üzerinde oluşan gölgelerin oldukça yoğun (sert) olduğu gözlemlenmiştir. Gölgeler nitelikleri bakından ışık kaynaklarının tek bir yönde olması ve karşıt yönde ışık kaynağı bulunmaması bakımından sert-kara gölgelerin sıkça oluştuğu söylenebilir. Bu durum, aydınlık ve karanlık alanlar arasındaki kontrastı arttırırken dikkatin sanat nesnelerine çekilmesini de sağlamaktadır. Oluşan kara gölgelerin ilk bakışta fark edilmemesine sebep olarak koyu renk yüzeyler gösterilebilir. Müzenin ana sergileme mekânının duvar ve tavanları 
koyu yeşil renk boyalıdır. Sergileme ünitelerinde de devam eden bu renk seçimi ile mekân, nötr-yansız bir ortama dönüştürülmüş, izlenilmesi istenen nesneler ön plana çıkartılmış ve ziyaretçilerin bu nesneleri en iyi şekilde algılaması sağlanmıştır.

Döşemede kullanılan çıta şeklinde masif ahşap malzeme, izotrop yayınık yansıma yapan mat malzeme olduğu için sergileme yüzeylerine ait görüntülerin döşeme üzerine düşmemesi ve yansımadan kaynaklanan kamaşma sorunlarına neden olmaması bakımından doğru bir seçimdir. Ancak aydınlatma elemanının doğrultusu sebebiyle döşeme üzerinde yer yer ışık lekelerine rastlamak mümkündür.

\subsubsection{Sürekli Sergileme Mekânında Aydınlatmanın Neden Olduğu Bozulmalar}

Sergileme ünitelerinin, ziyaretçilerin nesnelere dokunmasını engelleyen vitrinlerinin içerisinde ve nesnelerin kimlikleri hakkında bilgi veren etiketlerinde, LED aydınlatma kullanılmıştır (Şekil 14). Kullanılan 12V DC LED trafosuna sahip şerit LED'ler ile vitrin içerisinde meydana gelebilecek ısınmalar engellenmiş ve sergilenen çok duyarlı nesneler üzerinde oluşabilecek fiziksel ve kimyasal bozulmaların önüne geçilmiştir.

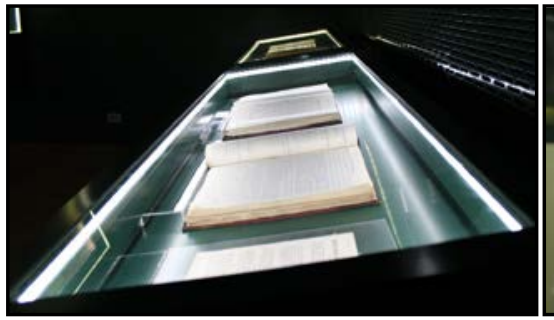

Şekil 14: Osmanlı Bankası Müzesi vitrin içi sergileme üniteleri ve açıklama etiketleri (Yazar

Sürekli sergileme mekânlarında eserlerin belirli süreler içerisinde aydınlatılması, oluşabilecek bozulmaların önüne geçmek için tercih edilmesi gereken bir uygulamadır. Çünkü aydınlatma süresi yıpratıcılıkla doğru orantılı olarak artmaktadır. Lambaların sağladığı UV ışınımları kontrol altına almak, bu ışınımların zararlarından korunabilmek için görünür ışınımlara saydam, görünmez ışınımlara opak süzgeçler takıldığı görülmüştür.

Osmanlı Bankası Müzesi'nin sürekli ana sergileme mekânında aydınlatma sistemi müzenin ziyaretçiye açık olmadığı saatlerde kapatılmaktadır. Kasa daireleri ile bu dairelere geçişi sağlayan koridorlar ise harekete duyarlı aydınlatma sistemi ile aydınlatılmaktadır. Böylece müze ziyaretçiye açık olsa dahi mekânlar içerisinde ziyaretçi yoksa aydınlatma sistemi otomatik olarak kapanmaktadır. Bu sistem sayesinde aynı zamanda enerji tasarrufu da sağlanmaktadır.

\subsection{Osmanlı Bankası Müzesi Süreli Sergi Mekânı Aydınlatma Uygulamaları}

SALT Galata'nın -1. katında bulunan sergileme mekânı $410 \mathrm{~m}^{2}$ dir (Şekil 15). Restoran ile sadece dış duvarları tasarlanan mekânın içerisinde herhangi bir bölücü bulunmamaktadır. Duvarları beyaza boyanıp nötr bir ortam yaratılan sergileme mekânı her sergi için yeniden düzenlenmektedir. 


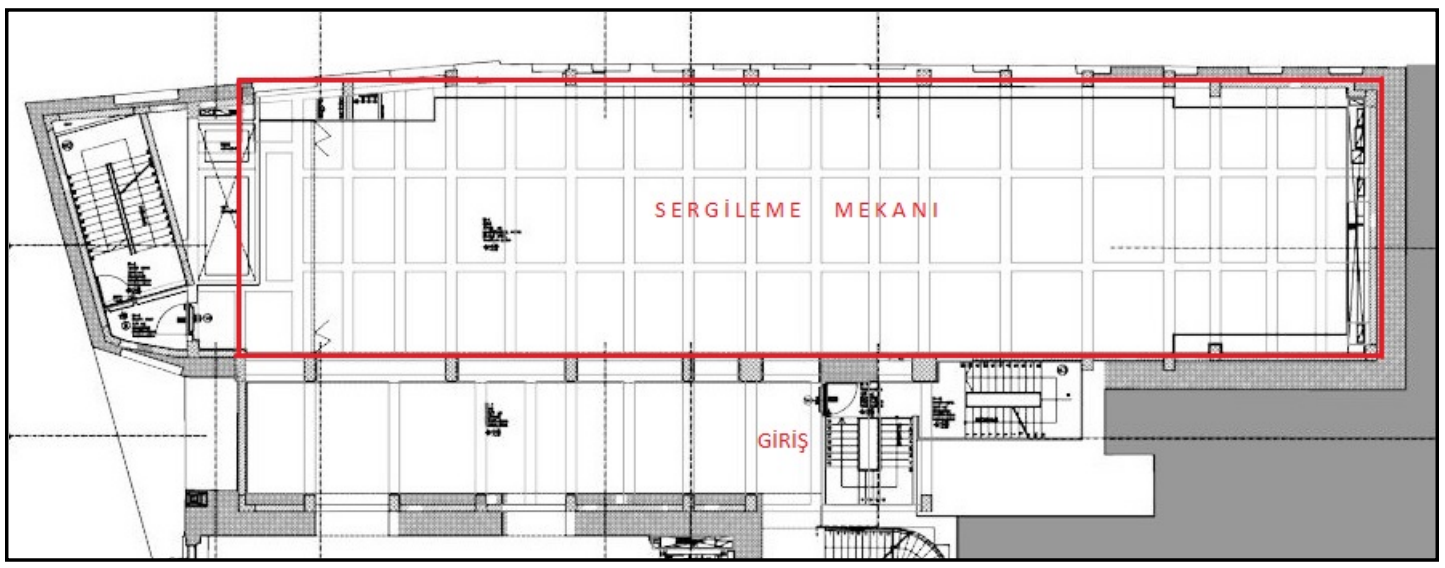

Şekil 15: SALT Galata süreli sergileme mekânı plan şeması (Url-6'dan yararlanılarak yazar tarafından hazırlanmıştır).

\subsubsection{Aydınlatmanın Niceliği Bakımından Süreli Sergileme Mekânı}

-1. katında bulunan süreli sergileme mekânın içerisinde pencere olmadığı için doğal aydınlatmadan yararlanılamamaktadır. Tümüyle yapay aydınlatma düzeni ile aydınlatılan mekânın aydınlatma sistem çözümü, restorasyonda korunan tavana yerleştirilmiş ray sistem ile çözülmüştür (Şekil 17). Kullanılan aydınlatma elemanları, Osmanlı Bankası Müzesi sürekli sergileme mekanında da kullanılmış olan Panavision Lumiere aydınlatma elemanıdır. Mekân için tasarlanmış esnek sistem üzerinde, her bir sergi için gerekli olacak sayıda armatür yerleştirilebildiği gibi projeksiyon benzeri ek unsurların adaptasyonu da sağlanabilmektedir.
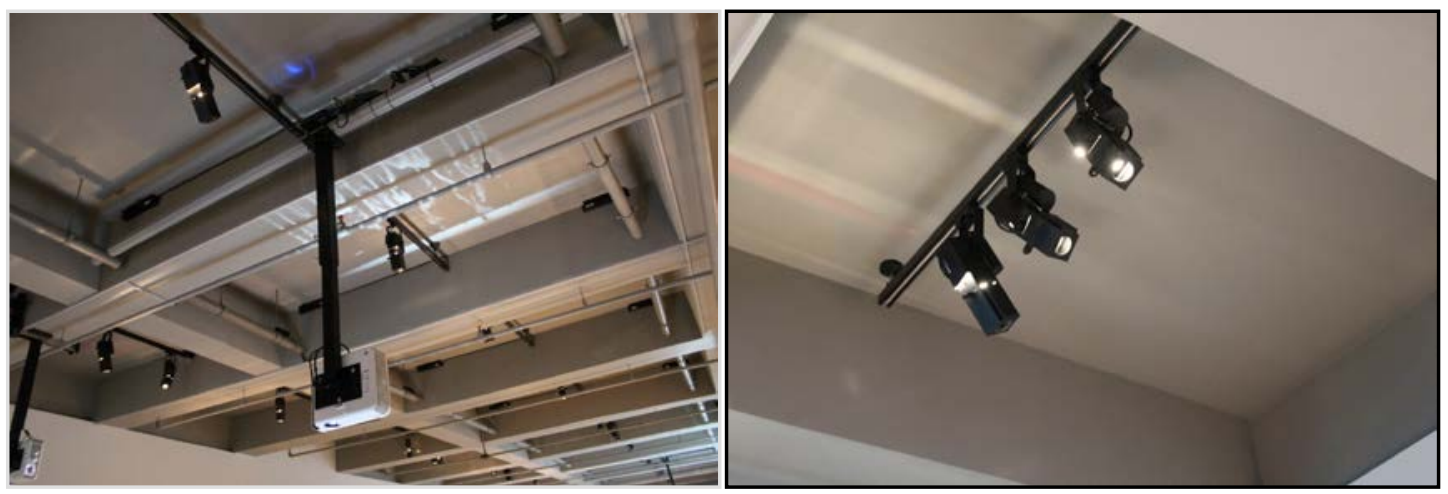

Şekil 17: SALT Galata süreli sergileme mekânı aydınlatma sistem ve elemanları (Yazar Kişisel Fotoğraf Arşivi).

\subsubsection{Aydınlatmanın Niteliği Bakımından Süreli Sergileme Mekânı}

-1. katında bulunan süreli sergileme mekânda kullanılan lambalar, ışık rengi bakımından çeşitlilik göstermektedir. Bu durum, sergileme mekânında sergilenecek nesneler özelinde bir ışık uygulaması yapıldığını düşündürtmekle birlikte kullanılan ışık renklerinin mekânın genel özellikleriyle uyumlu olmadığını da göstermektedir. 


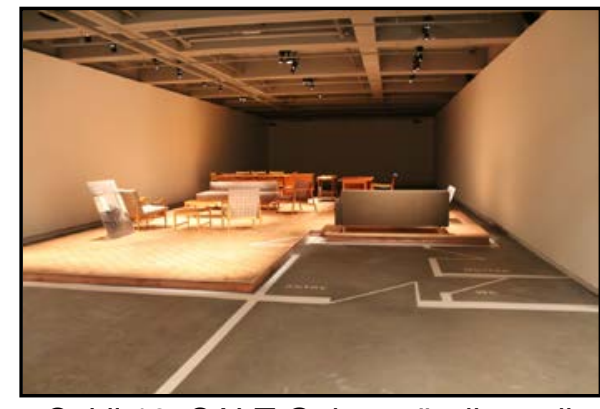

Şekil 18: SALT Galata süreli sergileme mekânında sergi uygulama örnekleri (Yazar Kişisel Fotoğraf Arşivi).

Mekânda kullanılan ışığın doğrultusal yapısı, diğer mekânlardaki gibi direkt-dolaysız aydınlatma biçimi oluşturacak şekilde tavandan zemine doğru yönlendirilse de homojen bir aydınlık elde edilememiştir. Mekânda kullanılan aydınlatma armatürleri ile bölgesel aydınlatma sağlandığı için çoğu bölgede duvar yüzeyleri üzerinde ışık lekeleri oluşmaktadır. Aynı zamanda bazı bölümlerde, mekânın fiziksel özellikleri sebebi ile aydınlatmanın doğrultusuna bağlı olarak sergileme yüzeyine düşen gölgeler oluşmaktadır (Şekil 18-19). Gereğinden fazla ışık kullanıldığı durumlarda ise zemin üzerinde, ziyaretçiyi mekânı dolaşırken rahatsız eden ışık patlamaları meydana gelmektedir. Bu durum zemin ve duvarlarda kullanılan malzemelerin yansımalarının kontrol edilemediği fikrini oluşturmaktadır. Bu olumsuz duruma neden olarak kullanılan yapay aydınlatma elemanlarının aydınlatılacak yüzeylere oldukça yakın yerleştirilmiş olması gösterilebilir.
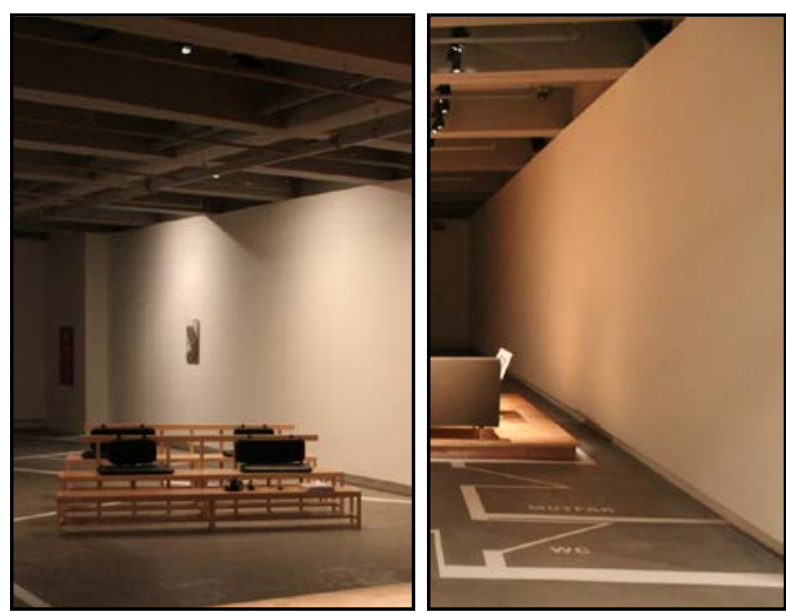

Şekil 19: SALT Galata süreli sergileme mekânındaki duvarlarda oluşan gölgeler (Yazar Kişisel Fotoğraf Arşivi).

Oluşan ışık patlamaları, gölgelerin niteliğini de etkilemektedir. Bölgesel olarak oluştuğu gözlemlenen sert-kara gölgeler, zaman zaman yerlerini saydam gölgelere bırakmaktadırlar. Bu durum, aydınlatmanın niteliğini doğrudan etkilediği gibi uzun vadede mekân içinde kazalara da neden olma potansiyeli taşımaktadır.

Süreli sergileme mekânlarında sergilenen sanat nesneleri belirli sürelerle geçici olarak bu mekânda bulundukları için aydınlatmanın neden olduğu bozulmalar tespit edilememiştir. Bu nesneler özelinde sergi mekânındaki yapay aydınlatmalardan kaynaklanan bozulmaların tespit edilmesi için daha detaylı bir çalışma yapılmasına intiyaç vardır. Çalışma için ayrılan araştırma süresi kısıtlı olduğundan dolayı süreli sergi mekânında aydınlatma kaynaklı bozulmalar konusuna değinilmemiştir. 


\section{Sonuç ve Tartışma}

Görsel algının sağlanabilmesi, bilinçli bir aydınlatma tasarımının uygulanması ile doğru orantılıdır. Öncelikli olarak yapılması gereken; mekânda sergilenecek olan nesnelerin özelliklerinin belirlenmesi ve duyarlııklarına göre sınıflandırılmasıdır. Bu sınıflandırmaya göre, eserlerin sergileneceği ortamlar için sağlanacak olan aydınlığın nicelik ve nitelik özellikleri belirlenmelidir. Duyarlııkları birbirinden farklılık gösteren eserlerin birarada ve aynı aydınlatma tekniği ile sergilenmesi bazı eserler üzerinde bozulmalara sebep olduğu görülmüştür.

Çalışma kapsamında incelenen Osmanlı Bankası Müzesi sosyal ve tarihsel bilgi birikimini içinde barındıran bir müzedir. Koleksiyonunun önemli bir kısmının kağıt malzemeden oluşması, sergileme tipinin, sergileme süresinin ve uygulanacak aydınlatma tekniğinin önemi arttırmaktadır. Yapılan araştırma sonucunda müzede tercih edilen ileri yapay aydınlatma teknolojileri ile birlikte zararlı ışınımların eserlere zarar vermesinin belirli ölçüde engellendiği; fakat görsel konfor koşullarının kısmen gözardı edildiği anlaşımıştır. Görsel konfor koşullarının sağlanmasında olumsuz etkileri olan; yansıma, kamaşma gibi ziyaretçiyi rahatsız edecek olumsuz durumların sürekli ve süreli sergileme mekânlarında yaygın olduğu görülmüştür. Bu durum zaman zaman ziyaretçinin eserleri rahatça incelemesini engellemektedir.

Müzede sürekli sergileme mekanlarında aydınlık düzeyi yeterli bulunurken süreli sergileme mekanlarında ise aydınlık düzeyi iyileştirilebilir. Bu duruma neden olarak, her iki mekanda da aynı tip aydınlatmalar kullanılmasına rağmen mekanda tercih edilen malzemelerin yansıtılcılık özelliklerinin yüksek olması ve lambaların yanlış konumlandırılması gösterilebilir. Sürekli sergileme mekanında mekanlar arasında aydınlık düzeylerinde farklılıklar olduğu gözlemlenmiştir. Bu durum kamaşma ihtimalini arttırırken adaptasyonu da zorlaştırmaktadır. Sürekli sergileme mekanlarında aydınlatılacak nesneler değişmediği için aydınlatma elemanlarının nesnelerin renklerine uygun renk sıcaklıklarında seçildiği görülmüştür. Bununla birlikte süreli sergileme mekanında değişen nesneler için uygun ışık rengini sağlamak amacıyla farklı renk sıcaklığındaki lambaların birlikte kullanıldıkları gözlemlenmiştir.

Sürekli ve sürekli sergileme mekanlarının her ikisi de ışık akısının doğrultusal yapısı direkt-dolaysız aydınlatma biçimi sağladığı için benzer özellikler göstermektedir. Ancak oluşan gölgelerin nitelik özelliklerinin farklı olduğu gözlemlenmiştir. Sürekli sergileme mekanında sert gölegeler oluşurken, süreli sergileme mekanında ise gölgelerin çeşitli faktör olduğu kanısına varıımıştır. Sürekli ve süreli sergileme mekanlarının karşılaştırılması aşağıdaki tabloda gösterilmiştir. (Çizelge 3).

Çizelge 3: SALT Galata sergileme mekânları değerlendirme tablosu.

\begin{tabular}{|c|c|c|c|c|c|c|}
\hline & \multicolumn{3}{|c|}{ Aydınlatmanın Niceliği } & \multicolumn{3}{|c|}{ Aydınlatmanın Niteliği } \\
\hline & 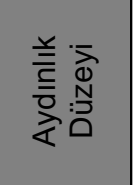 & 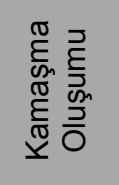 & $\begin{array}{l}\overline{0} \\
\frac{0}{\pi} \\
\frac{\pi}{0} \\
\frac{\pi}{0} \\
\frac{0}{<}\end{array}$ & 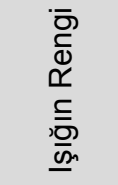 & 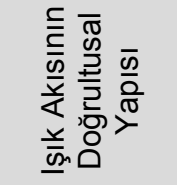 & 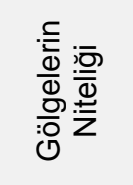 \\
\hline $\begin{array}{c}\text { Sürekli Sergi Mekânı } \\
\text { Ana Sergileme+ } \\
\text { Kasa Daireleri } \\
\end{array}$ & Yeterli & Yüksek & Düşük & $\begin{array}{c}\text { Sicak } \\
2700 \mathrm{~K}\end{array}$ & $\begin{array}{c}\text { Direkt } \\
\text { Aydınlatma } \\
\text { (Downlight) }\end{array}$ & $\begin{array}{l}\text { Sert } \\
\text { (Kara) } \\
\text { Gölge }\end{array}$ \\
\hline Süreli Sergi Mekânı & Yetersiz & Düşük & Yüksek & $\begin{array}{l}\text { Karışık } \\
2700 \mathrm{~K}- \\
4000 \mathrm{~K}\end{array}$ & $\begin{array}{c}\text { Direkt } \\
\text { Aydınlatma } \\
\text { (Downlight) }\end{array}$ & $\begin{array}{c}\text { Sert } \\
\text { (Kara)+ } \\
\text { Saydam } \\
\text { Gölge }\end{array}$ \\
\hline
\end{tabular}


Müzede karşılaşılan sorunların giderilmesi için karşılıklı düşey sergileme yüzeyleri, yansımayı önleyecek şekilde yeniden tasarlanmalıdır. Özellikle cam, ayna, cilalı ahşap gibi malzemelerin kullanımı, çevredeki nesnelere ait görüntülerin sergileme yüzeyleri üzerine yansımasına sebep olmaktadır. Bu durumun giderilmesi gerekmektedir. Ana mekânda kullanılan camlı vitrinlerde bu durum ziyaretçiyi rahatsız edecek, sergilenen nesnelerin okunmasını engelleyecek düzeydedir. Bu sorunu ortadan kaldırmak için aydınlatma aygıtlarının yansıma bölgesinin dışına konumlandırılması, düzgün yansımaya sebep olan malzemelerin eğimli olarak yerleştirilmesi veya malzeme değişikliğine gidilerek, izotrop yayınık yansıma yapan mat yüzeyli malzemelerin tercih edilmesi yeterli olabilecek çözümler arasındadır.

Müzelerin ziyaretçide bıraktığı olumlu izlenimler, öncelikle kendisinin bu mekânlara tekrar gelmesini ve etrafındaki insanlara da tavsiye etmesini sağlayacağı için mekânda uzun süreli kalma isteğine odaklanılmasının, istenmeyen etkilerin uygun çözümlerle ortadan kaldırılmasının olumlu sonuçlar doğuracağı düşünülmektedir.

\section{Kaynaklar}

Aktemur, A. M. (2005). Osmanlı Bankası'nın Tarihçe ve Mimarisi, Atatürk Üniversitesi Güzel Sanatlar Enstitüsü Dergisi, 0(15), 1-20.

Atagök, T. (1999). Müze Mimarisi. T. Atagök (Ed.), Yeniden Müzeciliği Düşünmek. İstanbul: Yıldız Teknik Üniversitesi Basım Yayın Merkezi.

Atagök, T. (2002). Müzelerin Anlaşıır Kılınması, İç Mekân ve Sergi Tasarımları. Mimarist, , 4, 55-59.

Atasoy, S. (1994). Müzelerimizde Sergileme Sorunları, 2.Müzecilik Semineri Bildiriler Kitabı (syf.99-100). Türkiye: Askeri Müze ve Kültür Komutanlığı, Eylül 19-23.

Autheman, A. (1988). Osmanlı Bankası'nın Tarihçesi, İstanbul: Osmanlı Bankası Arşiv ve Araştırma Merkezi Yayınları.

Bayer, Y. (2007). Sergi Salonu Aydınlatmasında Genel Illkeler ve Iki Sergi Salonunun Incelenmesi (Yüksek Lisans Tezi). Yıldız Teknik Üniversitesi, Fen Bilimleri Enstitüsü, İstanbul.

Demircioğlu Yıldız, N., Yılmaz, N. (2005). Işık Kirliliği, Ortaya Çıkardığı Sorunlar ve Çözüm Önerileri, Atatürk Üniversitesi Ziraat Fakültesi Dergisi, 36(1), 117-123.

Dokuzer Öztürk, L. (1992). Kent Aydınlatma İlkeleri, Yıldız Teknik Üniversitesi Yayınları No: 247, Mimarlık Fakültesi Yayınları No: MF-MiM 92.036, İstanbul

Erbay, M. (2011). Müzelerde Sergileme ve Sunum Tekniklerinin Planlanması, İstanbul: Beta Yayınları.

Erkün Oruçoğlu, Z. (1999). Müze Sergilemesinde Dil ve Etkileşim. T. Atagök (Ed.), Yeniden Müzeciliği Düşünmek. İstanbul: Yıldız Teknik Üniversitesi Basım Yayın Merkezi.

Fitoz, İ. (2011). Aydınlatma Şekilleri, Mimar Sinan Güzel Sanatlar Üniversitesi Fen Bilimleri Enstitüsü, İç Mimaride Aydınlatma Yüksek Lisans Dersi Notları, İstanbul.

İmert, H. (2010). Aydınlatmanın Amacı, Professional Lighting Design, 33(4), 24-26. 
Karahan, A., Demir, A., Özdoğan, E., Öktem, T., Seventekin, N. (2007). Tekstil Malzemelerinin Yüzey Modifikasyonlarında Kullanılan Bazı Yöntemler, Tekstil ve Konfeksiyon Dergisi, 17(4), 248-255.

Kurtay, C.,Aybar, U., Başkaya, A., Aksulu, I. (2003). Müzelerde Algılama ve Aydınlatma Kriterlerinin Analizi: Ankara- Anadolu Medeniyetleri Müzesi Orta Holü, Gazi Üniversitesi Mühendislik-Mimarlık Fakültesi Dergisi, 18(2), 95-113.

Küçükdoğu, M.Ş. (2010). Mimarlıkta Aydınlatma: Antalya Mimarlık Konferansları 2010, Antalya: Mimarlar Odası Antalya Şubesi Yayınları.

O'Doherty, B. (2010). Beyaz Küpün İçinde: Galeri Mekânının Ideolojisi (Ahu Antmen, Çev.). İstanbul: Sel Yayıncılık.

Özdeniz, M. (1996). Aydınlatma Tasarımında Yeni Yaklaşımlar. 1. Ulusal Aydınlatma Kongresi Bildiri Kitabı (syf. 38-44), İstanbul: İstanbul Teknik Üniversitesi, Kasım 28-29.

Ritter, A., Ritter, J. (2011). Mimari-Sanat-Işık, Professional Lighting Design, 38(3), 4249.

Sirel, H. (1992). İç ve Dış Aydınlatma Konularının Karşılaştırılması, Şehir Aydınlatması Kolokyumu (syf. 7-17), Kocaeli: TMMOB Elektrik Mühendisleri Odası, Mart 23.

Sirel, H. (1999). Müze Eşyasının Korunması ve Sergilenmesi ile Aydınlatma İlişkisi. T. Atagök (Ed.), Yeniden Müzeciliği Düşünmek. İstanbul: Yıldız Teknik Üniversitesi Basım Yayın Merkezi.

Sirel, Ş. (1990). Müze Aydınlatması ve Resim Sergileme Yüzeyleri Ille Illgili Bir Uygulama, İstanbul: Yapı Fiziği Uzmanlık Uygulamaları Yayınları.

Şentürk, Z. D., Berksan, Z. S., İcinli, Y. (2003). Osmanlı Bankası Binası ve Müzesi, İstanbul: Yıldız Teknik Üniversitesi.

Turner, J. (1998). Designing with Light: Public Places: Lighting Solutions for Exhibitions, Museums and Historic Spaces (Designing with Light Series), Brighton and Hove: RotoVision Publishing.

Uyan Dur, B. I. (2011). Çevresel Grafik Tasarım'ın Uygulama Alanları, Sanat ve Tasarım Dergisi, 1(7), 159-178.

Ünver, F. R. (1996). Mağaza Aydınlatması, 1. Ulusal Aydınlatma Kongresi Bildiri Kitabı (syf. 64-71), İstanbul: İstanbul Teknik Üniversitesi, Kasım 28-29.

\section{İnternet Kaynakları}

Url-1: www.tdk.gov.tr, Türk Dil Kurumu Türkçe Sözlüğü (Erişim Tarihi: 03.05.2021)

Url-2: $\quad$ https://icom.museum/en/resources/standards-guidelines/museum-definition, International Council of Museum Resmi Web Sitesi (Erişim Tarihi: 02.05.2021)

Url-3: www.gozlemevi.omu.edu.tr, Elektromanyetik Spektrum, Ondokuz Mayıs Üniversitesi Gözlemevi Yayınları, (Erişim Tarihi: 06.05.2021) 
Url-4: www.obarsiv.com, (Erişim Tarihi: 03.06.2013)

Url-5: www.saltonline.org, (Erişim Tarihi: 27.04.2021)

Url-6: http://www.arkiv.com.tr/proje/salt-galata1/4709, Arkitera Mimarlık Arşivi (Erişim Tarihi: 02.05.2021)

Url-7: $\quad$ https://www.mimarizm.com/haberler/salt-galata-hem-kentin-hem-bolgeninarastirma-ussu-olacak_117095, Mimarizm Mimarlık ve Tasarım Yayın Platformu (Erişim Tarihi: 02.05.2021)

Url-8: www.ypsilontasarim.com, (Erişim Tarihi: 04.05.2021)

Url-9: www.fr.audiofanzine.com, (Erişim Tarihi: 25.05.2013)

Url-10: www.jpb-audiovisuel.fr, (Erişim Tarihi: 25.05.2013)

Url-11: www.lightco.fr, (Erişim Tarihi: 25.05.2013)

Url-12: www.sylumis.com, Panavision Aydınlatma Kataloğu, (Erişim Tarihi: 25.05.2013) 